NIST

PUBLICATIONS

\title{
Conformity Assessment Workshop on Wood Products
}

\section{Robert L. GladhllI}

U.S. DEPARTMENT OF COMMERCE Technology Administration National Institute of Standards and Technology Office of Standards Services Gaithersburg, MD 20899 



\section{Conformity Assessment Workshop on Wood Products}

Robert L Gladhill

U.S. DEPARTMENT OF COMMERCE Technology Administration National Institute of Standards and Technology

Office of Standards Services

Gaithersburg, MD 20899

March 1992

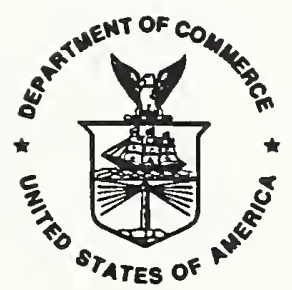

U.S. DEPARTMENT OF COMMERCE

Barbara Hackman FrankJin, Secretary MATIONAL INSTTUUTE OF STANDARDS AND TECHNOLOGY

John W. Lyons, Director 



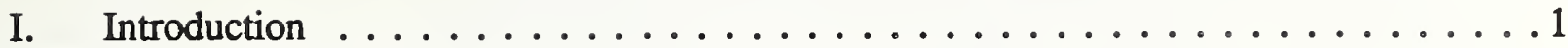

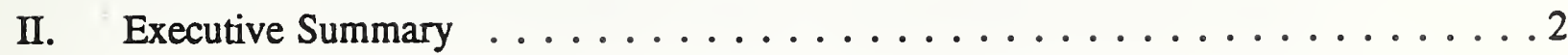

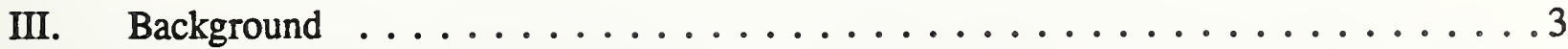

IV. Formal Presentations $\ldots \ldots \ldots \ldots \ldots \ldots \ldots \ldots \ldots$

V. Questions from the Audience and Responses ............... 6

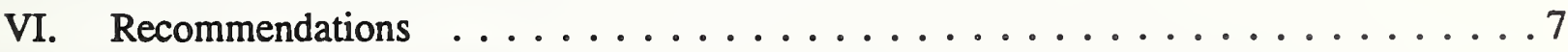

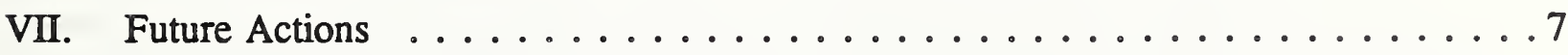

Appendices

A. Panel Members and Attendees $\ldots \ldots \ldots \ldots \ldots \ldots \ldots$

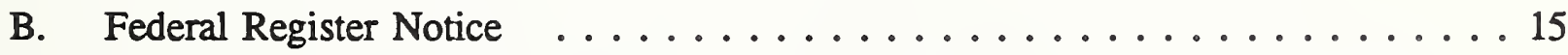

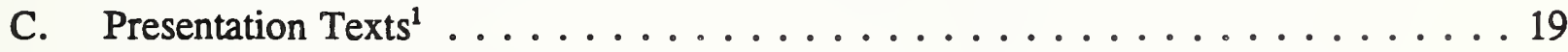

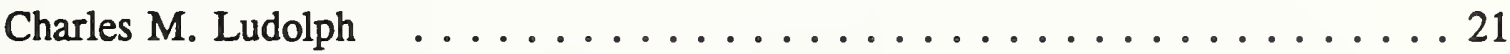

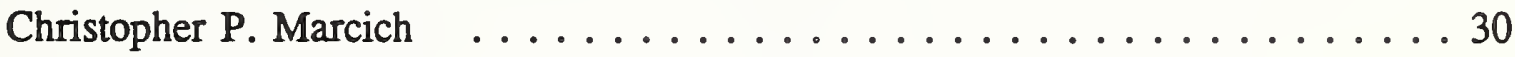

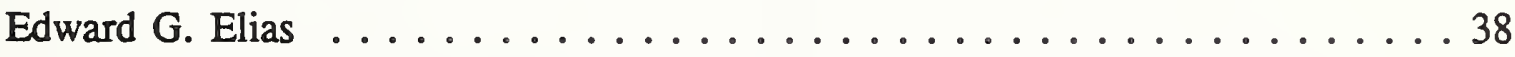

Thomas D. Searles . . . . . . . . . . . . . . . . 4 41

Mike Hoag (for William McCredie) $\ldots \ldots \ldots \ldots \ldots \ldots$

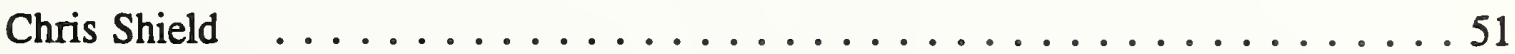

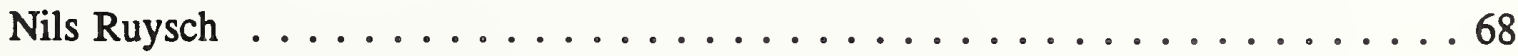

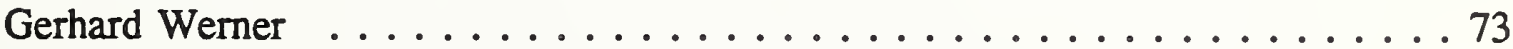

${ }^{1}$ Material in Appendix $\mathrm{C}$ was provided by the panelists. 



\section{Introduction}

The National Institute of Standards and Technology (NIST) is co-sponsoring a series of workshops with various private sector groups to identify the needs for coordination and representation of U.S. conformity assessment interests abroad. The subject of the first workshop, held in January 1991, was Pressure Vessels (NISTIR 4542); the subject of the second, held in April 1991, was Electromagnetic Compatibility (NISTIR 4611).

On November 6, 1991, a third workshop, concerning the Wood Products Industry, was cosponsored by NIST, the American Plywood Association (APA), the National Forest Products Association (NFPA), and the American Lumber Standards Committee (ALSC). The purpose was to explore ways in which the U.S. Government might assist that industry in conformity assessment activities in order to gain acceptance of its products in such international markets as the European Community (EC).

The recommendations stemming from the three workshops clearly indicate that those industrial sectors believe that the U.S. Government should assume an active role in assisting and/or representing them with regard to national and international conformity assessment issues. 


\section{Executive Summary}

In April 1990 the National Institute of Standards and Technology (NIST) conducted a hearing at which a panel of government experts explored possible ways the government could serve the needs of U.S. industry in international standards development and conformity assessment. One of the conclusions in the analysis of the hearing record (NISTIR 4367) states that "The Government should sponsor or co-sponsor with interested parties from the private sector a series of workshops with various industry sectors...".

As a result, on November 6,1991, a Wood Products Industry Workshop was held at the U.S. Department of Commerce Building, Washington, D.C., co-sponsored by NIST, the American Plywood Association (APA), the National Forest Products Association (NFPA), and the American Lumber Standards Committee (ALSC). The purpose was to explore ways in which the U.S. Government could assist that industry in conformity assessment activities aimed at gaining acceptance of its products in such international markets as the European Community (EC).

Sixty-two persons attended the workshop. Ten individuals made formal oral presentations (see Appendix C), and 21 participated in a panel discussion.

The following recommendations were reached by consensus of the workshop panelists:

1. The United States Government (USG) should serve as a clearinghouse for information on quality assessment requirements that producers will need to satisfy if they wish to participate in the EC market.

2. The USG should establish a wood products sector advisory committee to assist in the development of U.S. positions for negotiations with the EC on matters relating to standards and conformity assessment.

3. The USG should take an active role in accrediting U.S. conformity assessment programs and seek recognition of that activity as satisfying EC directives for conformity assessment.

4. The USG should negotiate an agreement with the EC that would address the scope and authority of EC Notified Bodies to subcontract product testing and quality assessment to qualified U.S. testing and inspection agencies.

5. The wood products sectoral advisory committee should strive, in concert with code and enforcement officials as well as wood products approval bodies, to develop a national accreditation program for testing and certification. The USG should assist the sectoral advisory committee accordingly. 


\section{Background}

In July 1989, the Department of Commerce (DOC) conducted a two day hearing to determine U.S. private sector interests in the European Community's standard development and conformity assessment efforts.

In April 1990, NIST conducted a hearing at which a panel of Government experts explored possible government roles to serve the needs of U.S. industry in international standards and conformity assessment. Sixty-five organizations and individuals made oral presentations, and 257 additional written comments were submitted for the record.

One of the conclusions in the analysis of the April hearing record (NISTIR 4367) states that "The Government should sponsor or cosponsor with interested parties from the private sector a series of workshops with various industry sectors to specify more precisely the needs for coordination and representation of U.S. conformity assessment interests abroad. Then appropriate systems should be developed to meet those needs and promote effective application of these mechanisms in behalf of U.S. manufacturers and exporters. Particular consideration should be focussed on the division of responsibilities between government and the private sector in a cooperative mode of operation."

The information obtained from the two hearings was thoroughly reviewed by the U.S. Government's Working Group on Standards and Conformity Assessment (testing, certification, laboratory accreditation, quality assessment, etc.). The working group's suggestions were embodied in the recommendations of the U.S. Government's Interagency Task Force on EC-92, the principal EC-92 trade policy development body of the U.S. Government. A section of the task force's three-part plan states that "... in association with the NIST workshops cosponsored with interested private sector groups on general issues of international interests in conformity assessment, the USG (U.S. Government) should take advantage of this opportunity to seek the potential needs of industry to EC-92 'new approach' testing and certification."

Thus, representatives of various industrial sector sponsoring organizations, in consultation with NIST officials, organized a series of workshops. The Wood Products Workshop was the third in the series.

The workshop was held on November 6, 1991 at the Department of Commerce Building in Washington, D.C. It featured twenty-one distinguished panelists, of which 10 made formal presentations. The panelists represented domestic and international wood products trade associations, the U.S. Government, testing laboratories, manufacturers representatives, and code groups. There were a total of sixty-two attendees, including panelists.

The workshop was co-chaired by Mr. Richard C. Enlow, Manager, Technical Support Building Products, Georgia Pacific Corporation, and Mr. Mark Kempe, Manager, Export Marketing \& Operations, Wood Products Division, International Paper. 


\section{Formal Presentations}

The following individuals made formal oral presentations at the workshop. After these presentations the panel entered into a discussion of the issues raised. A copy of all speakers remarks are included in Appendix C.

\section{Samuel Kramer, Deputy Director, National Institute of Standards and Technology}

In opening remarks Mr. Kramer welcomed the participants. He conveyed the Secretary of Commerce's view that EC-92 presents a top priority challenge to increase the volume of U.S. exports. The United States currently exports to the EC alone about $\$ 95$ billion annually. The total annual U.S. exports throughout the world constitutes only $7 \%$ of the U.S. gross national product (GNP), whereas our major trading partners export approximately $19 \%$ of their GNP; the U.S. figure must be increased.

Mr. Kramer added that (1) increasing U.S. exports to the EC means getting U.S. standards and conformity assessment activities in order, and (2) finding ways to assure transparency with EC partners in standards development and conformity assessment. Transparency will also help the United States monitor standards and conformity assessment procedures for products which are regulated in the EC but unregulated here.

Mr. Kramer concluded by urging the panelists to develop recommendations on how the U.S. Government should contribute to solving these and other issues.

\section{Charles M. Ludolph, Director, Office of European Community Affairs, International Trade Administration, Department of Commerce}

Mr. Ludolph presented an overview of the European Community and its impact on the construction industry. He spoke of the harmonization of building regulations, building codes, standards and test methods, and conformity assessment procedures.

\section{Christopher P. Marcich, Deputy Assistant U.S. Trade Representative For Europe and the Mediterranean}

Mr. Marcich provided an overview of the importance of a single market in Europe. He spoke of the importance of the workshops to keep government informed of the problems industry is having so that it can provide appropriate assistance. He indicated the importance of standards, certification and testing, and expressed the U.S. concern with the EC handling of these issues.

Mr. Marcich discussed some possible solutions for U.S. manufacturers to meet EC directives. He indicated that there will be some transitional problems which may take time to work out. He also discussed some plans the Government has to deal with these issues. 
Mr. Elias presented an overview of the APA and its mission. He indicated that APA has already established agreements with several European countries without the help of government. However, due to APA's involvement in the Canadian Free Trade Agreement negotiations, APA realizes that government involvement is essential in these type of matters.

Mr. Elias called for the government to establish a National Accreditation System that would represent the United States and negotiate with the EC to establish "Notified Bodies" in the United States. He also called for the Government to establish a system to accredit Quality System Registrars.

Thomas D. Searles, Executive Vice President, American Lumber Standards Committee (ALSC)

Mr. Searles presented an overview of the ALSC and its mission. He indicated that the ALSC has participated in the EC standards-writing for lumber. He discussed the ALSC interest in the EC and its interest in continuing working with the ALSC in standards development. He stated that if the EC requires U.S. Government involvement in conformity assessment, then we need to explore how to accomplish that.

\section{Mike Hoag, Technical Director, National Particleboard Association (NPA)}

Mr. Hoag presented an overview of the NPA and its mission. He discussed differences between EC and U.S. testing standards. He indicated that the U.S. Government, in close concert with the private sector, can play a major role in promoting mutual recognition agreements with other countries. He stated that it would be desirable to have organizations equivalent to "Notified Bodies" in the United States, and to eliminate duplicative testing.

Mr. Hoag discussed the standards and testing conditions applicable to NPA members.

\section{Chris Shield, Timber Research and Development Association (TRADA), U.K.}

Mr. Shield presented an overview of TRADA and its mission. He also presented an overview of the U.K. Government role in certification and accreditation e.g., NAMAS, NACCB. He indicated that agreements are being made between EC members and the United States, as well as sub-contracting arrangements between the U.S. and EC members. He indicated that the U.K. will continue to rely on U.S. timber imports. 
Mr. Ruysch presented an overview of SKH and its mission and an overview of how the certification process works in the Netherlands. He stated that U.S. interests should become observing members of EC standards bodies and then they could have some influence over the standards. He indicated that the Netherlands, as the U.K., depends upon U.S. lumber imports.

\section{Gerhard Werner, Forshungs und Materialprufungsanstalt Baden-Wurttemberg (FMPA) Otto Graf Institut}

Mr. Werner presented an overview of the FMPA and its mission. He discussed how to be in accordance with the EC standards and how to use the EC mark. He also discussed the quality standards ISO 9000 series and their impact.

\section{Questions from the Audience and Responses}

During the workshop, persons in the audience were invited to submit written questions to the panel for response by appropriate panel members. The questions and responses are summarized below.

Question: How long does it currently take for approval in Germany?

Response: Usually about one year. It depends on many things, such as timing of committee meetings, type of conformity assessment required, or where the tests are performed.

Question: We manufacturers need the CE mark on our products if we are going to sell in the EC. However the means of acquiring the CE mark is not established - Is this correct?

Response: The need for the CE mark is defined for regulated products, and it will have to be applied sometime between 1992 - 1999, depending on the implementation date of the applicable standard. The means to apply the mark in Europe are available now and are awaiting the standards. The ability to apply the mark in the United States is still cloudy but may clear up by the end of the year. It may be accomplished at least through subcontracting. 
Question: In exchange for recognition as a duly authorized Notified Body, would the NPA and APA accept certifications by competent European organizations of products for sale in the United States, i.e., will NPA and APA allow use of their product marks/gradings by competent European certifiers testing to U.S. standards?

Response: Up to now we have had no such requests. We currently have reciprocal agreements with several European entities. This can be a subject for negotiation.

Question: Where no appropriate European standard exists for manufactured engineered wood products, will the EC consider use of existing U.S. standards?

Response: Yes! We already use many ASTM standards, especially when they are better than ours. We also use many U.S. standards as the basis for our standards.

\section{Recommendations}

The chairmen presided over a general panel discussion of the issues stated in the Federal Register Notice. During the deliberations the workshop recommendations were formulated.

Based on the panel discussions and the formal presentations, the following recommendations were put forth and unanimously adopted as representing the views of the workshop panelists.

1. The United States Government (USG) should serve as a clearinghouse for information on quality assessment requirements that producers will need to satisfy if they wish to participate in the EC market.

2. The USG should establish a wood products sector advisory committee to assist in the development of U.S. positions for negotiations with the EC on matters relating to standards and conformity assessment.

3. The USG should take an active role in accrediting U.S. conformity assessment programs and seek recognition of that activity as satisfying EC directives for conformity assessment.

4. The USG should negotiate an agreement with the EC that would address the scope and authority of EC Notified Bodies to subcontract product testing and quality assessment to qualified U.S. testing and inspection agencies.

5. The wood products sectoral advisory committee should strive, in concert with code and enforcement officials as well as wood products approval bodies, to develop a national accreditation program for testing and certification. The USG should assist the sectoral advisory committee accordingly. 


\section{Future Actions}

NIST is collecting and reviewing recommendations from this workshop and the previous workshops, and is scheduling additional workshops. NIST is formulating a plan for the U.S. Government to assist U.S. industry in gaining acceptance of U.S. products abroad. Information will be transmitted to cognizant authorities for selection of the most appropriate courses of action. 
Appendix A

Panel Members and Attendees 
Thomas D. Searles

Executive Vice President

American Lumber Standards Committee

19715 Waters Road

Germantown, MD 20875-0210

Mike Hoag

National Particle Board Association

18928 Premiere Court

Gaithersburg, MD 20879

Christopher Marcich

Deputy Assistant

U.S. Trade Representative Office

600 17th Street, NW

Washington, DC 20506

Charles M. Ludolph

U. S. Department of Commerce

International Trade Administration

Washington, DC 20230

John W. Lyons

U. S. Department of Commerce

Director, National Institute of

Standards \& Technology

. Gaithersburg, MD 20899

Edward G. Elias

American Plywood Association

Tacoma, WA 98411

Stanley I. Warshaw

U. S. Department of Commerce

National Institute of Standards

\& Technology

Gaithersburg, MD 20899

Chris Shield

Timber Research \& Development Association

(TRADA)

United Kingdom

Nils Ruysch

Stichting Keuringsbureau Hout (SKH)

The Netherlands
Gerhard Werner

FMPA Baden-Wurttemberg

Pfaffenwaldring 4

7000 Stuttgart 80/Vaihingen

Germany

Richard C. Enlow

Manager, Technical Support

Building Products

Georgia-Pacific Corporation

2883 Miller Road

Decatur, GA 30035

Marke Kempe

International Paper Company

P. O. Box 809024

Dallas, TX 75380-9024

John A. Mentis

Director

International Trade

National Forest Products Association

1250 Connecticut Avenue, NW, Ste 200

Washington, DC 20036

Mr. Robert Glowinski

American Wood Council

1250 Connecticut Avenue, NW, Ste 200

Washington, DC 20036

Mr. Don Wallace

Western Wood Products Association

522 SW Fifth Avenue

Portland, OR 97204-2122

Mr. Wilbur Hammond

Thomas Hammond \& Sons

Hampshire Street

East Hiram, ME 04041

Mr. Larry Blum

USDA Foreign Agricultural Service

Room 4647-S

14th \& Independence Avenue, NW

Washington, DC 20250 
Mr. Tom Jones

Southern Pine Inspection Bureau 4709 Scenic Highway

Pensacola, FL 32504-9094

Mr. Benjamin W. Ingram, III

Charles Ingram Lumber Co., Inc.

Rt. \#2, Box 381

Effingham, SC 29541

Dr. Erv Schaffer

Assistant Director

Wood Products Research

U.S. Forest Products Laboratory

One Gifford Pinchot Drive

Madison, WI 53705-2398

Mr. Terry Kassabaum

Technical Services

Champion International Corporation

P. O. Box 200

Farm Road 62

Camden, TX 75934

Mr. Kurt Stochlia, P.E.

Vice-President

ICBO Evaluation Service, Inc.

5360 South Workman Mill Road

Whittier, CA 90601

Mr. D. W. Blankenship

Director, Marketing and Sales

Composite Products Division

Weyerhaeuser

Corporate Headquarters

Tacoma, WA 98477

Mr. George F. Kimmerling

Senior Editor

Laboratory Regulation News

BURAFF Publications

1350 Connecticut Avenue, NW

Washington, DC 20036

Mr. David I. Granger

Clifford \& Warnke

Attorneys and Counsellors at Law

815 Connecticut Avenue

Washington, DC 20006
Ms. Susan E. Pethiunas

Manager, U.S. Government Affairs

Manville Corporation

$1625 \mathrm{~K}$ Street, NW, Ste 750

Washington, DC 20006

Mr. Ward Hitchings

National Wood Window \& Door

Association

1250 Connecticut Avenue, NW

Washington, DC 20036

Mr. Michael Hicks

Director, Forest Products Division

U.S. Department of Commerce

International Technology

Administration

Rm. 4045

14th \& Constitution Avenue

Washington, DC 20230

Mr. Randy Webb

Prof. Service Industries, Inc.

Pittsburgh Testing Lab. Division

545 Conger Street

Eugene, OR 97402

Mr. Jim Munnerlyn

Western Region Vice President

Prof. Service Industries, Inc.

Pittsburgh Testing Lab. Division

545 Conger Street

Eugene, OR 97402

Mr. Richard A. Flores

International Plywood Manager

Boise Cascade Corporation

P. O. Box 62

Boise, ID 83707

Mr. Doug Steinman

President

Merger Modular Homes

300 Moss Hill Lane

Sailsbury, MD 21801 
Mr. Richard Conley

Director of Engineering

Merger Modular Homes

300 Moss Hill Lane

Sailsbury, MD 21801

Ms. Laura Stonitsch

International Trade Commission

500 E Street, SW

Washington, DC 20436

Ms. Lori Hylton

Presidential Management Intern

International Trade Commission

500 E Street, SW

Washington, DC 20436

Mr. Bradley E. Shelley

Executive Vice President

West Coast Lumber Inspection Bureau

P. O. Box 23145

Portland, OR 97223

Mr. Joseph R. Piscione, P.E.

Manager of Product Acceptance

TRUS Joist Corporation

9777 West Chinden Boulevard

P. O. Box 60

Boise, ID 83707

Mr. Jerry Johnson

General Manager

Timberco, Inc.

Research, Testing \& Quality

Assurance

86305 College View Road

Eugene, OR 97405

Mr. Rich Margosian

National Particleboard Association

18928 Premiere Court

Gaithersburg, MD 20879

Mr. Ronald W. Willis

Export Markets Manager

Southern Forest Products Association

P. O. Box 641700

Kenner, LA 70064-1700
Mr. Robin W. Grover

Keck, Mahin \& Cate

1201 New York Avenue, NW

Penthouse

Washington, DC 20005-3919

Mr. Ron Anthony

Technical Director

Engineering Data Management, Inc.

4700 McMurray Avenue, \#A

Fort Collins, CO 80525

Mr. E. T. Altman

President

Hardwood Plywood Manufacturers

Association

1825 Michael Faraday Drive

P. O. Box 2789

Reston, VA 22090

Mr. William J. Groah

Technical Director

Hardwood Plywood Manufacturers

Association

1825 Michael Faraday Drive

P. O. Box 2789

Reston, VA 22090

Mrs. Jamie Rothschild

Marketing Specialist

Forest Products Division

USDA Foreign Agricultural Service

14th \& Independence Avenue, NW

Washington, DC 20250

Mr. Chris Twarok

Forest Products Division

USDA Foreign Agricultural Service

14th \& Independence Avenue, NW

Washington, DC 20250

Mr. Jack Minneci

V-P for Codes and Standards

Am. Inst. of Timber Construction

11818 S.E. Mill Plain Blvd.

Suite 415

Vancouver, WA 98684 
Marc Janssens

National Forest Products Association

1240 Connecticut Avenue, NW

Suite 200

Washington, DC 20036

Peter Yurcisin

American National Standards Institute

11 West 42nd Street

New York, NY 10036

John Sebelius

USDA Forest Service

CF

P. O. Box 96090

Washington, DC 20090-6090

Jeff Shapiro

ICBO Evaluation Service, Inc.

5360 South Workman Mill Road

Whittier, CA 90601

John McDaniel

American Lumber Standards Committee

19715 Waters Road

P. O. Box 210

Germantown, MD 20875-0210

Mary Gabriel

Reutters News Service

1333 H Street, NW

Washington, DC 20005

Mark Felsenthal

Bureau of National Affairs

1231 25th Street, NW

Washington, DC 20037

Keith A. Mowry, P.E.

Manager, Governmental Affairs

Underwriters Laboratories Inc.

818 18th Street, NW

Suite 400

Washington, DC 20006
Sara E. Hagigh

International Trade Specialist

U.S. Department of Commerce 14th \& Constitution Avenue, NW

Room 3036

Washington, DC 20230

Kate O'Connor

Coordinator Cross-Industry Program

National Forest Products Association 1250 Connecticut Avenue, NW

Washington, DC 20036

C. Eric Olsen

Consultant

Manville Corporation (Chambers

Assoc.)

Suite 200

$1625 \mathrm{~K}$ Street, NW

Washington, DC 20006

James Gross

NIST

226/B250

Gaithersburg, MD 20899

Roger Rensberger

NIST

101/A903

Gaithersburg, MD 20899

Robert Gladhill

NIST

101/A629

Gaithersburg, MD 20899 
Appendix B

Federal Register Notice 


$$
\text { - }
$$


Improving Acceptance of U.S. Products in International Markets; Opportunity for Interested Parties T Attend and Observe

AGencr: National Institute of Standar and Technology. Commerce.

Action: Notice of workshop.

summarr: This is to advise the public that the National Institute of Standard and Technology (NIST) is cosponsorin a Wood Products Workshop with the National Forest Products Association, the American Plywood Association, a! the American Lumber Standards Committee. This is the third in a series of workshops designed to gather information, insights, and comments tc determine conformity assessment related activities (testing, certification. accreditation, quality assessment, etc. in which the U.S. Government can ass U.S. industry in gaining product acceptance within other markets such the European Community (EC). Suggestions for future workshops are invited.

Dates: The workshop will be held on November 6, 1991, at 9:30 a.m. in room 4830, U.S. Department of Commerce. 14th Street and Constitution Avenue. NW. Washington, DC 20230. The request to attend and observe the workshop should be received by October 18, 1991.
FOR FUPHeen mFophatmont canract. Dr. Stanley L. Werghaw, Director, Office of Standarda Services, National Institurte of Standarts and Tectmology.

Admiristration Building, room A-603, Grithersbur. MD 20699. Telephone 301975-4000. FAX 301-963-2871.

Aoomess: The workshop will be held in room 4830, the U.S: Department of Commerce, 14th Street and Constitution Avenue, NW. Washington, DC 20230 . SUPPLEMENTARY MFORMATIONE Consistent with the growing importance of internationed standardization and conformity assessment to the United States NIST is cosponsoring a Wood Products Workshop with the National Forest Products Association, the. American Plywood Association, and the American Lumber Standards Committee to solicit views and recommendations on how the U.S. Govermment can assist this sector of U.S. industry in gaining product acceptance within international markets such as the EC.

Tentative topics for discussion at the workshop are listed below. Sponsors of individual workshops may identify. specific issues focused on their sectors.

1. Which EC requirements for conformitty assessment are applicable to your sector?

2. Do the Europeas regional standards (i.e. CEN atandards for lumber, ptywood particleboard and other forest products: or international standarda (i.e. ISOl that apply to your sector differ from U.S. standards?

3. To what extent do you feef that U.S. conformity assessment systems relating to your sector are adequate for acceptance of test data or other attestations of corformity by the EC member states?

4. Would yow sector benefit fram developing muturat recognition agreenents betwreen U.S. kaboratories or product certifiers and their EC sounterparts?

5. How can the U.S. Government better utilize private sector input when developing official positions with regard to possibte negotiations with the EC for your sector for regudated products?

6. Should " $C E$ " marks of conformity be made acceptable in the U.S. marketplace? What are the Fiability implications of such acceptance?

7. Does your sector need a recognizable mark of conformity? Is a U.S. mark needed?

The workshop wilt be held on Wednesday. November 6th; 1991 at 8:30. a.m. in room 4830 , the U.S. Department of Commerce, 14th Streer and Constitution Avenue, NWW, Washington, DC 20230. To grarantee spece, persums. who wish to attend and observe the workshop should submit a notice in writing to Dr. Stanley I. Warl-ow. Director, Office of Standards Services, National Institute of Standands. and Technolegr. Admiristration Boilding: Room A-603. Gaithersburg, MD 20899. FAX 301-963-2871. Requests should contain the person's name, address. telephone and facuimike aumbers, and affiliations. Requests should be received by October 18, 1991.

Dated. September 4 , 1992

Joho W. Lyons,

Dinector:

[FR Doc. 91-21024 Fifed a-9-91: 8.45 amf ORUANO COOE \$5ro-13-M 

Appendix C

Presentation Texts 

THE EUROPEAN COMMUNITY PROGRAM FOR

CONFORMITY ASSESSMRNT IN WOOD PRODUCTS

\author{
PRESENTATION BY \\ CHARIES $M$. LUDOLPH \\ INTERNATIONAL TRADE ADMINISTRATION \\ U.S. DEPARTMENT OF COMMERCE
}

NOVEMBER 6, 1991 
OVERVIEW - The European Community is istensifying its efforts to create the legal and technical foundations for a single European market for goods and services by eliminating technical trade burfiers created by differences in the laws and regulations applied among its member states and their effect on trade among the 12 member countr1es.

Safety and health is a primary focus in both the EC directives and in standards and testing rethods used throughout the $\mathrm{EC}$. The BC intends to establish a system that harmonizes the national legal requirements for safety and health in sensitive product sectors through one set of harmonized product safety legislation, new European product standards and a unified European mandatory conformity assessment program. In effect, the European Community expects that all product that has a significant safety aspect to it must meet harmonized requirements. Only product that meets these harmonlzed requirements will be sold in the EC and product meeting these reguirements will have the right of free circulation throughout the now 12 member countries of the EC.

This general plan to create a single market affects conformity assessment and market access that depends on standards in the wood product industry. In particular, on December 21, 1988, the 12 EC countries adopted legislation that harmonizes laws, regulations and administrative provisions related to construction products, including all wood products that would be sold in the European Community for incorporation into bulldings. This legislation called the construction products directive (89/106) has not boen implemented yot because several related pieces of legislation need to be completed before implementation can be applied.

What the Construction Products Directive Does,

Before the harmonization process, each EC member stato developed and maintained its own national building regulations, building codes, building product standards and test methods, certification programs, and local enforcement. At all or any one of these levels EC member states differed among themselves one the character of requirements with tho regult that products approved in one jurlsdiction would not necessarily be approved for another.

As a result of the harmonizing activities going on in the European Community, in the early or mid-1990's Europeans will apply single EC-wide law that will (1) replace national building regulations with harmonized legislation, (2) introduce EC-wide buliding codes in the form of interpretative documents, and (3) generate uniform standards, test methods and (4) conformance assessment procedures. All of these features when implemented will be applied in a uniform manner by the same local enforcement administrations. 
Because so much attention was paid to the target date of 1992 . it is a common misconception that the single market program will be realized all at once sometime in 1992. A lot of things will happen in Europe in 1992 but not related to standards and technical factors in the construction products sector. Many hundreds of technical specitlcations must be developed for thousands of kinds of construction products before the system can be epplied. At the time of this conference, Europeans are working to complete the second part of the four stage process noted above. The EC Commission is completing araft interpretative documents on mechanical stability and load factors, heat ratention, sanitary, fire, and noise. With these completed in early 1992, the European private sector standards community can intensify drafting of standards, codes, and test methods to meet the essential safoty requirements in these legislated isterpretive documents. Standards drafting may take as much as an additional 3 to 5 years or longer. OnIy when the standards are completed will the EC Commlssion authorize the application of Directive 89/106. By that time the Europear Community will also have developed guidelines for approvals and the body of certifying entities in the EC to complete the implementation of the directive. At this point, perhaps in the mid-1990s, marufacturers of cosstruction products must comply with all applicable aspects of the 89/106 airective or they w1ll not be able to sell in the EC market.

\section{What Must U.S. Manufacturers Do?}

Until the EC Commission fully implements the directive by completing and applying harmonized standards, U.S. manufacturers may continue to gell in Burope on the same basis as they have been selling in the past. At some point in the 1990's however, the EC Will be prepared to apply the harmonized standards and the diractive on construction products and at this point manufacturers must comply with very distlnct requirements. Nost particularly, all construction products must display a mark of attestation as shows in the appended table. This "CE mark" is mandated to be on all construction products in order for it to be sold. This mark has very particular meaning. Iegally it demonstrates that the requirements of all applicable EC regulations have been met. Legally, it means that the product is "fit for use" in appropriate applications and that building inspectors cannot deny the use of marked products for appropriate use anywhere in the European Community. 
Commercially the mark has much more implications. Because the mark allows the consumer to distingulsh between "gelf-certified" and "third party certified" products, between products manufactured with a factory quality control system and without, and between a product assessed in one country versus another country, the manner of marking can be specified by the purchaser as an additional means to compete. That 1s, a purchaser has the right to specify that a product must bear a certain typo of CE mark to qualify and this could have an effect on competitiveness and pricing.

\section{What About Conformity Assessment?}

As indicated above, ultimately manufacturers will be expected to conform to European standards. Conformity assessment methods depend on the nature of the product, the nature of the production process, and the application. Means of conformity assessment include some form of declaration or certilication of the existence of a factory production control system, type testing or sample testing. Depending on the product, a third party may be involved in any of these steps to conformity assessment. In the tabular Index is a table that summarizes the means to assess conformity. Further information can be obtalned from the source listed at the end of this chapter.

Generally the EC provides for a system of conformity assessment that does not provide for third party conformity assessment to be carried out in the United states. In fact, EC conformity assessment is the responsibility of notified bodies designated by EC member state governments and existing only within the political boundarles of the EC. The means to obtain certiflcations therefore relies on European standards and European certifiers. The USTR will address the expectations for getting U.S. based certifiers in this process.

In the absence of appropriate products standards in Europe, the EC proviaes for the manufacturer to obtain techntcal approvals from another set of European "certifiers" and based on test methods and standards or specifications adapted specifically to the product. In this case, entities known as European Organization for Technical Approval (EOTA) will issue five year approvals of products, renewable, that permits the marketing of construction products on an BC-wide basis. Guidelines for these procedures will be elaborated in 1992. 
CONCLUEION The matters before this working group are to determine the ability of 0.5 . manufacturerg and exporters in the United states to compete in this system boing applied in the Europear Community to construction products. Typically. manufacturers prefer to produce product to one standard, perform one test, and that test and certificate would be issued near or in the factory. This is the ideal. This ideal did not exist in all EC markets before EC 1992 and the construction products directive came along. But from this standpoint, the European Community initiatives are not 1deal. You must conduct tests in Europe to European standards and European test methods: none of which will be similar to the U.S. experience. The purpose of this workshop is to set out what is needed to maintain competitiveness in Europe after 1992. The U.S. government is primarily interested in what is good for manufacturars and exporters and the service organizations that help them compete. 
BEFORE EC 1992 :

- EC MEMBER STATES ESTABIISHED

NATIONAL OR SUBNATIONAI BUIIDING REGUIATIONS

NATIONAI OR SUBNATIONAI BUILDING CODES

NATIONAI PRODUCT STANDARDS

NATIONAI OR SUBNATIONAL RULES FOR TESTING, CARTIFICATION AND MARKING

SUBNATIONAI MEANS FOR ENFORCEMENT 
ACTIVITIES

1. EC-WIDE DIRECTIVES PREEMPT MS BUILDING REGULATION

CONSTRUCTION PRODUCTS WORKPLACE SAFETY

2. " EC-WIDE "INTERPRETATIVE DOCUMENTS" PREEMPT BUILDING REGUIATIONS AND BUILDING CODES

3. EURO-CODES PREEMPT MS BUILDING CODES TIMBER, CONCRETE, STEEL MASSONRY;, SEISMIC

4. EC-WIDE HARMONIZED PRODUCT STANDARDS PREEMPT NATIONAI STANDARDS AND TEST METHODS.
EFFECT

BUILDINGS

CHARACTER
BUILDING CHARACTER

AND PERFORFANTCE OF MATERIAIS

CHARACTER OF BUILDINGS AND PRODUCTS

CHARACTER OF PRODUCTS

\section{PRODUCT CLASSES AND IEVELS (FITHESS FOR DSE)}

5. HARMONIZED CERTIFICATION AND PRODUCT MARKING PREEMPT NATIONAL SYSTEMS (PITNESS FOR USE)

6. WATIONAI AND SUBNATIONAI ENFORCEMENT (FITNESS FOR USE)

\section{CHARACTER OF PRODUCTS}

CHARACTER OF PRODUCTS

SAFEGUARDS 


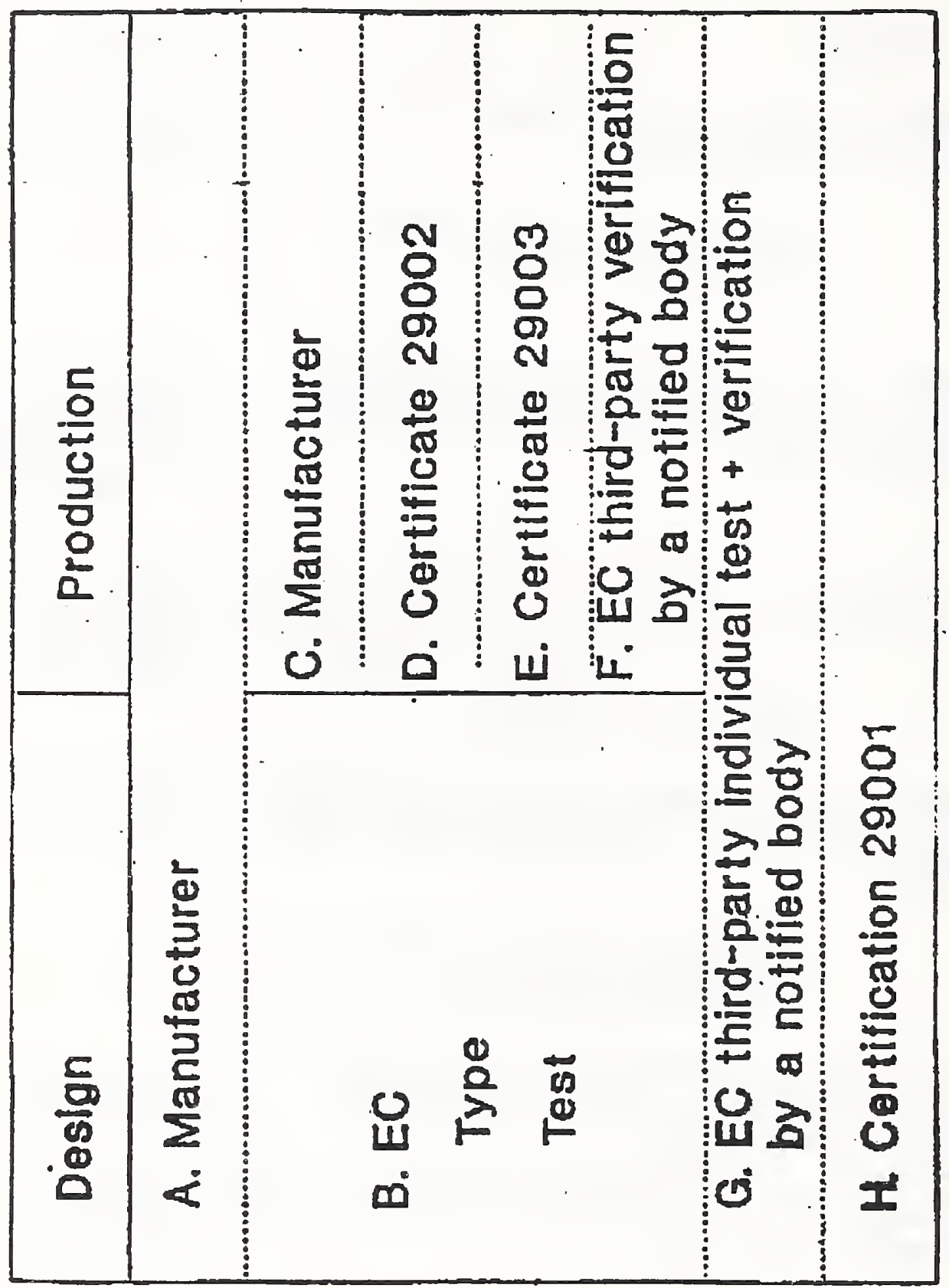



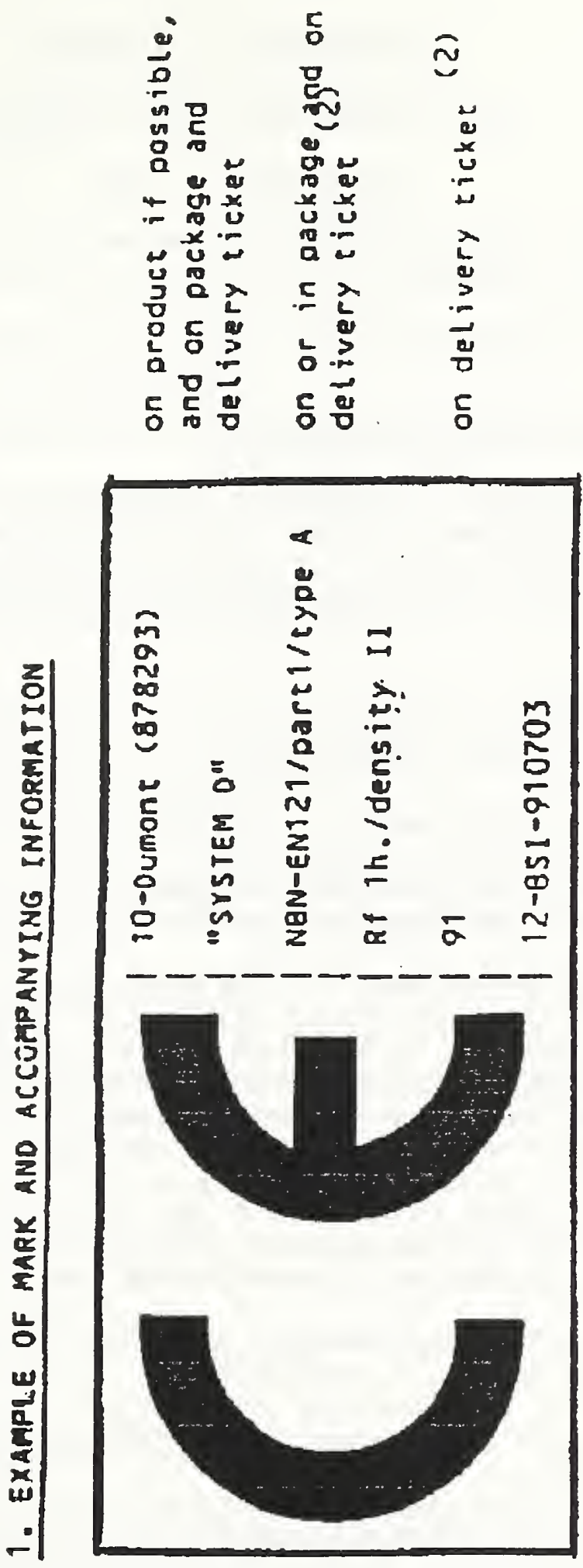


\section{CHRISTOPHER P. MARCICH}

NIST WORKSHOP--WOOD PRODUCTS

November 6, 1991

- Speaking Notes -

I. OVERVIEW

Importance of single Market

- harmonization, economies of scale

- now spreading to EFTA, Eastern Europe

USG Activities: 92 Task Force/Working Groups

II. INTRODUCTION

Important role of workshops

-- inform government of industry needs and concerns

-- ensure that industry has adequate information on which to make informed decisions and provide advice

Key questions set out in Federal Register notice

- particularly interested in views on whether wood products community would benefit from mutual recognition agreements between U.S. laboratories or product certifiers and EC entities

-- If so, what role should the U.S. government play? What role should the private sector play? These are key questions we will have to sort out soon

Issue of standards, testing and certification in the single market is extremely important

-- for many industries, will determine degree of access to the single market

- the top priority issue for the U.S. Government with regard to the single market in 1991 and possibly beyond

-- important that the U.S. Government and the U.S. private sector work together closely to ensure that U.S. interests are addressed satisfactorily 
III. U.S. CONCERNS

The broad outlines of the testing and certification system being created by the EC are by now familiar

-- set out in the 1989 "Global Approach" document and 1989 Council Declaration

-- EOTC system for non-regulated sectors

A few salient points:

Establishing this system is a major undertaking, which is not proceeding as rapidly or as smoothly as originally envisioned by the EC Commission

-- if constructed and implemented in an open, nondiscriminatory manner, system should facilitate trade flows with the community and between the community and its trading partners

- if not done in this manner, could cause disruptions in trade flows, increased costs for U.S. exporters, and result in U.S.-EC trade disputes

System as presently proposed denies foreign manufacturers and conformity assessment entities adequate access

-- proposed system requires that conformity assessment must be done by "notified bodies" within the EC

-- costly, time consuming, and often duplicative

Potentially places U.S. manufacturers at a competitive disadvantage vis-a-vis European competitors

-- must secure access to EC notified bodies

-- may limit ability to be first to market with new products

Also prevents U.S. conformity assessment entities from participating in conformity assessment activities for the single market

-- for small entities, this is a direct threat to their continued economic viability 
U.S. objective:

-- secure adequate access (for both U.S. manufacturers and conformity assessment entities) on sufficiently flexible terms

-- ensure that U.S. manufacturers and conformity assessment entities receive national treatment in the single market. 
IV. POSSIBLE SOLUTIONS

A. SELF CERTIFICATION

As a general rule, to the greatest extent possible, EC directives for the single market should provide for manufacturers self-declaration of conformity with single market standards

- easiest, least disruptive, cost-efficient means

-- may not be applicable in all product sectors

B. SUBCONTRACTING

EC currently contemplates subcontracting by notified bodies of certain activities to entities outside the community

- potentially a partial solution to concerns of U.S. manufacturers and conformity assessment entities

-- would reduce costs for manufacturers and provide a certain degree of access for conformity assessment entities

- remains to be seen how much interest there will be in such arrangements on the part of notified bodies in the EC and entities in the United states

Scope of permissible subcontracting activities is unclear and must be clarified

-- testing only? and only by bodies authorized to do more than just testing?

-- evaluative functions?

- quality systems aưdits?

Provisions defining permissible subcontracting activities should not be the subject of negotiations between the EC and its trading partners

-- should be determined by regulation 
Recent EC Commission working document represents an effort to clarify terms and conditions for subcontracting

-- a step in the right direction, clarifies some of above questions

-- allows for quality systems audits

-- allows for the inclusion of quality assessment activities

-- also establishes artificial divisions of responsibility between notified bodies and sub-contractors (technical vs. assessment operations)

A flexible approach is needed in order to provide incentive for European notified bodies to enter into subcontracting arrangements. Recent commission actions are promising.

\section{MUTUAL RECOGNITION AGREEMENTS}

Possibility exists for the conclusion of mutual recognition agreements between the EC and its trading partners in various sectors

-- a potential means for U.S. manufacturers to satisfy conformity assessment requirements for their products in the United States; and

-- for U.S. entities to engage in the full range of conformity assessment activities for the single market

As presently contemplated by the EC, the terms and conditions for mutual recognition agreements present a number of serious problems

-- involves the assumption of certain obligations by U.S. entities

- implies acceptance of results of activities conducted by EC notified bodies and marks conveyed by them

-- meshing of different regulatory systems in which products may be regulated in the EC and not in the U.S. and vice-versa

Key question of role of government versus that of the private sector--EC attempting to project its philosophy onto U.S. 
-- EC will require a "guarantor" of the competency of "notified bodies" in the United states -- the U.S. government;

-- at present, this role is played by the private sector in most sectors

- recent indications seem to suggest that the EC may be willing to accept an "equivalent" guarantor -- i.e., accreditation systems run by the U.S. private sector

An insistence on reciprocity ("balanced situation")

- conditioning access to the single market on reciprocity requirements is unacceptable to the U.S.

- the U.S. market in general, and testing and certification schemes in particular, are open to EC products and firms

- no additional "benefits" exist to be gained by the EC through such agreements

Recent EC Commission paper represents an effort to clarify some of these issues and suggests some flexibility

- some clarification of the notion of "mutual benefits"

-- suggestion of the possible acceptance of private sector accreditation programs in lieu of a governmental guarantee of the competence of U.S. conformity assessment entities

-- potentially a step backward on the terms of a "balanced situation"

- national treatment should suffice, but indications are EC will apply addtiional criteria such as looking at technical rules, administrative conditions for market access, and geographical restrictions

These issues will need to be addressed satisfactorily in order for the USG to determine whether entering into mutual recognition agreements with the EC is desirable. 
EC is falling behind in creating the standards required for the single market and constructing accompanying conformity assessment regime - e.g., decision to postpone implementation of the EMC directive

-- European standards-setting bodies (CEN and CENELEC) haven't been able to generate standards rapidly enough to keep up with EC directives

-- as a result, deadines for implementing EC directives have been postponed

-- conformity assessment procedures have not yet been implemented on an EC-wide basis

-- member states continue to demonstrate a great reluctance to accept each other's notified bodies

Requirements that will prevail during this interim period remain to be determined

-- EC must take steps to deal with the potential confusion in order to ensure that trade is not disrupted; and

-- to prevent certain member states from using confusion as an excuse to impose/retain protectionist measures

U.S. exporters should be prepared for a period of uncertainty until single market directives are fully implemented

EC has proposed some ideas to make the process more efficient--but probably not in time to make a difference in meeting the 1993 deadline. 
VI. NEXT STEPS

U.S. and EC Commission have initiated and maintained a useful dialogue on standards, testing and certification issues

-- we plan to continue to use this dialogue to address the problems described above

Expect the Commission to secure a mandate from the EC council soon to begin negotiations on mutual recognition agreements

-- the U.S. government will need to decide whether to negotiate such agreements; and

-- if so, for which sectors and under what conditions

-- also need to weigh the alternatives, e.g., subcontracting, self-certification; and

-- the interests of various U.S. industries

Finally, we must sort out the respective roles of the U.S. government and the private sector in this process

VII. CONCLUSION

-- Issues before the workshop today are of great importance

-- We'll need your advice -- and that of other industries -- in order to make informed decisions on these issues

-- We look forward to working closely together in the coming months in order to address these issues satisfactorily 


\section{APA PRESENTATION AT NIST-INDUSTRY COSPONSORED EC-92 WOOD PRODUCTS WORKSHOP}

I suspect most of you are familiar with the American Plywood Association and the scope of its activity with respect to product certification validation and testing. Nevertheless, the wood products industry is quite diverse, so it may be best for me to start with a little background on APA.

APA has been involved in product quality testing and certification validation for more than 50 years. Third party testing and certification validation is actually required by Product Standard PS 1-83. A similar requirement is incorporated in a new standard being processed now that will cover any wood based panel that meets defined performance requirements. Products include plywood mat-formed products like oriented strand board and composite panels.

NOTE: Should include general description of program

APA has also been active in international market development for more than 25 years. In pursuing that market development activity, we have been successful in establishing credibility for U.S. products that have been produced under our third party quality validation program. In fact, in many cases, that is what has unlocked the door to product acceptance in an offshore country.

In Europe, we have secured product approvals in several countries, based on assessment of our quality testing and validation program. Some of the offshore control organizations with whom we have negotiated approval agreements are here today, and I will review what they anticipate their role will be in the ' 92 unified market. These approvals have all been the result of face-to-face discussions without involvement of the U.S. Government and without the specter of EC-92. They include United Kingdom, the Netherlands, and Federal Republic of Germany. Other European countries in which we have gained regulatory acceptance for U.S. structural panel products are Belgium, Denmark, Sweden, Norway, France, Italy, Spain and Ireland. In most of those agreements, our organization is subject to an annual audit of our records for the control agency of the European country, which we certainly agree is appropriate. In its discussion with the EC, the USG should strive to retain recognition for that type of arrangement.

Most recently, we have been deeply involved in many of the negotiations the Department of Commerce and the U.S. Trade Representatives Office have had with Canada on the Canadian Free Trade Agreement, and with Japan in connection with the Structural Impediments Initiative, and Super 301 activity of the 1989 Trade Act. Our involvement with government in these most recent instances has given us an appreciation 
for how important it is to have an industry/government working relationship in dealing with trade issues with other governments. This will be particularly important in facing the requirement of the European unified market in '92, as we see it.

Currently, we are involved, along with three other organizations, in efforts to secure recognition as an accredited certification organization in Canada. This has been handicapped and certainly delayed by the fact the United States has no counterpart national certification accreditation system to that administered by the Standards Council of Canada.

While we have not yet faced similar problems in Europe, we anticipate they will be encountered as EC-92 unfolds. In that regard, the U.S. Government, in our view, should establish a national certification accreditation system that would call on NVLAP and other U.S. laboratory accreditation systems for support and actively seek "Notified Body" status with the EC. Negotiation of a mutual recognition agreement with the EC should also be pursued if that will be required. Such a national accreditation system has value well beyond the EC. It should have global application where other countries, such as Japan and Canada, have established accreditation systems. MRA's can be negotiated with those countries.

In the beginning, I made reference to the fact that the wood products industry is a diverse industry. Not all of the products produced by the industry will fall under the classification of a "regulated product." Wood products used structurally in building construction will fall in the "regulated category", but there are many products destined for non-structural use where a manufacturer's declaration of quality may be sufficient for market access. In those cases, quality assurance techniques meeting the scope and intent of the ISO 9000 series of standards may be all that is required. A manufacturer who uses a quality management system based on the ISO 9000 series standards and has that practice verified by a qualified certification validation organization, may find access to the regulated market as well.

This suggests that the USG also set in motion a vehicle that will accredit organizations that register and monitor manufacturers who may choose to use the ISO 9000 series standards.

Based on the understanding APA has of the EC-92 certification and testing issues and the progress we have previously made with product acceptance approvals in various EC countries, a number of questions come to mind that seem desirable to explore today. Let me advance five that seem most appropriate.

1. What mechanism can be established to function as an accreditor of existing U.S. accreditation systems so that those existing systems can continue to be recognized in the EC?

2. Is subcontractor status a means by which U.S. third party certification and testing organizations can continue to retain the recognition they have secured in EC countries? 
3. Can a procedure be established that will permit U.S. organizations to test to U.S. standards when they differ from EC standards if equivalency can be established.?

4. What is the wood products sector's view of designating export products with both domestic and EC trademarks where products meet the standards of both markets?

5. What is the wood products sector's view of using ISO 9000 QA standards as a means of recognition under a Quality Systems Registration program?

I'm sure the other speakers will also have questions that they wish to open for discussion. Our guests from Europe will certainly give us further enlightenment hat will help to establish our course. Hopefully, this process will lead us to some appropriate recommendations we can offer to the USG from the wood products sector that will highlight areas of major importance to a smooth transition between the EC and the United States as the unified market of Europe unfolds. 
My name is Tom Searles. I am Executive Vice President of American Lumber Standards Committee. I serve on ISAC 10, which is made up of various segments of the forest products industry, and IFAC 2, which is composed of standards writers and conformity assessment organizations from many industries. Both of these committees give advice to Secretary Mosbacher and Ambassador Hills. The ALSC, which was started in 1922, is a Committee appointed by the Secretary of Commerce composed of manufacturing representatives, distributors, consumers and users of softwood lumber. The standard establishes the sizes, measurement, grading principles and labeling of softwood lumber. Approximately 45-50 billion board feet per year are produced by manufacturers that use the services of an agency approved by the Board of Review of the ALSC. This represents 90-95\% of the U.S. consumption of which approximately $25 \%$ comes from Canada.

The value of US lumber exports has grown from approximately 650 million dollars in 1986 to approximately 1.4 billion dollars projected for 1991. The value going to the EC has grown from .5 billion to just over 1 billion projected for 1991. With inclusion of the EFTA countries in the EC these numbers would increase.

In addition to the standards writing function the ALSC elects a "Board of Review" whose functions are: 1) Approve grading rules (lumber specifications) as conforming to the ALS, 2) Approve agencies to grade under the approved rules and 3) sit in continuing review of adequacy, competency and reliability of service performed by such agencies. Simply stated the Board of Review accredits agencies to label lumber as conforming to the approved grading rules. The monitoring program is done by making random, unannounced visits at manufacturing plants that are using the service of an approved agency, by having the right to inspect lumber wherever it may be found and by reviewing the agency records to determine that all regulations are being followed. The accreditation service is available to any agency that can meet the criteria.

In the 1970's we participated in the writing of the EC standard for visual grades of softwood lumber and in writing the MSR standard and the fingerjoint standard. These standards are being used as the starting documents by CEN to write standards to conform to the new EC requirements. It is our understanding that these standards will be referenced in the Euro Code.

Our interest in EC-92 has been and is to try to follow the development of standards giving our views when possible so that our products would meet the EC standards with as few changes in size, grading, etc. as possible. We are also interested in accomplishing this goal by working with the various EC groups to find "common ground" between US and Europe.

Our interest regarding conformity assessment is to see that our conformity assessment systems are acceptable under the EC system and that our products are accepted in the EC countries. The EC should rest assured that when it receives products produced under the ALS conformity assessment system they meet the specifications indicated on the labels found on the products.

Today we have varying acceptance. In the UK we have good acceptance. Individual agencies have been accredited to grade under the UK grading rules and the individual agency marks are recognized. In other countries less so. It is yet to be determined if or how these marks will be accepted or if other schemes will be required.

The following is stated in the BSI response to the Green Paper "...it is not so much the standards but the different national testing and certification practices that need to be addressed if barriers to trade are to be removed... Differences in the interpretation of conformity assessment requirements and inconsistent and potentially arbitrary enforcement measures threaten to undermine the operation of the single market long after relevant European standards have been adopted." I agree with the assessment. If our products are to continue to be acceptable in the EC countries we need to consider 
how best to accomplish this. So far what we are doing has worked and is working. Do we need to change. If the EC is going to require the involvement of the U.S. government to give them assurance that our conformity assessment organizations meet whatever requirements are established be they the ISO guides or whatever then we need to explore how to accomplish these requirements.

In summing up here are some specific questions which come to mind:

1) Which products are going to be regulated and to what degree?

2) What mark will be required and what will it mean?

3) What is the timeframe that standards will be implemented and the quality assurance schemes approved?

4) Will attestation of conformity by accreditors, certifiers and suppliers outside the EC be accepted?

5) Are our individual agency marks to be recognized?

6) What will such a system involving the US government cost?

7) Is there money and staff to accomplish this?

That, Mr. Chairman, concludes my remarks. 
COMMENTS OF THE NATIONAL PARTICLEBOARD ASSOCIATION

NIST/WOOD INDUSTRY WORKSHOP

WEDNESDAY, NOVEMBER 6, 1991

Introduction

The National Particleboard Association (NPA) represents the domestic particleboard (PB) and medium density fiberboard (MDF) industries. The Association includes 19 companies with 44 manufacturing facilities which represents approximately $85 \%$ of the US manufacturing base of PB and MDF. NPA administers an independent Grademark program that includes in plant auditing of product quality assurance procedures as well as testing facilities for independent product testing and certification.

NPA's services to the PB and MDF industries includes the development of voluntary product standards and test methods. NPA monitors international standards activities and addresses standards issues that may affect PB and MDF industries. While US board manufacturers exported only $6.3 \%$ of their PB production and $13.5 \%$ of the ir MDF production in 1990, the European Community (EC) is considered to be an important potential market.

There are some clear differences between EC and US product and test methods. Most of these differences are associated with somewhat different product applications and at the moment do not present any substantial impediments to market access. On the other hand, differences in formaldehyde test methods and product emission requirements could present definite barriers to EC market access. In both the US and EC, product manufacturers, testing labs, and regulatory agencies are actively pursuing means of monitoring, assessing, and certifying formaldehyde emission levels from wood panel products. This current state of evolution of formaldehyde issues make universal product conformance testing even more important.

NPA believes that the US government, in close concert with private sector standards development organizations, can play a major role in promoting mutual recognition agreements and other product acceptance activities for the wood products sector. 
Following are NPA's comments on the questions posed for consideration at the NIST/Wood Industry Workshop:

Which EC requirements for conformity assessment are applicable to your sector?

There are two EC standards issues that are particularly relevant to the PB and MDF industries and to NPA. First, there is a clear need for US industries to have direct and prompt access to those entities, such as CEN, who are developing standards. It is our understanding that these standards will dictate the product requirements for all of the EC countries and are certain to have even broader international impact. The second issue is recognition of NPA's role as an independent testing and certifying organization. Clear guidelines for sub-contracting, or better, specific EC recognition of certified bodies within the US wood-based panels sector as equivalent to EC "notified" bodies, should be put in place at the earliest possible date.

Within the EC, PB and MDF standards development is under the jurisdiction of CEN/TC 112, Wood-based Panels. TC 112 consists of six working groups, of which four (WG1, WG3, WG4, and WG5) are dealing with some 49 standards of relevance to the $P B$ and MDF industries. Included in these standards are product definitions, specifications and test methods, including 3 formaldehyde test methods. The PB and MDF industries have had no direct contact with CEN on the development of these standards. In other words the standards development process has been more opaque than the desired "transparent".

NPA is not aware of any guidelines or mechanisms for non-EC organizations to become recognized within the $E C$ as being qualified to provide product certification and conformance testing. NPA's Grademark Program is widely recognized within the US. It provides testing and certification services to both NPA members and non-members, and to both domestic and foreign clients. In addition NPA has contracted with warious European organizations and US manufacturers in three party product quality assurance agreements. These contract arrangements are handled on a case-by-case basis, and are relatively time consuming to initiate and maintain as each has its own set of requirements. Due to the expense of establishing these agreements, it would 
clearly benefit US industry if NPA and other competent testing and certification organizations were recognized as the equivalent of "notified" bodies. These organizations would then properly be able to provide certification and conformance testing on an equal basis with EC "notified" bodies.

Do the European regional standards (i.e. CEN standards for lumber, plywood particleboard and other forest products) or international standards (i.e. ISO) that apply to your sector differ from US standards?

Though different from their comparable US standards, generally CEN and ISO standards do not at this time and as presently interpreted constitute substantial barriers for US manufacturers of PB and MDF. However, one area of major concern involves the test methods used to measure formaldehyde emissions from PB and MDF products. CEN/ TC 112/ WG 5 has responsibility for developing the formaldehyde test methods. Currently there are three formaldehyde test methods on the agenda for consideration. One of these, EN 120 - Perforator Method has been approved in a final form. The remaining two standards include a large chamber test method, which has a history of use in some of the northern European countries, and a small rapid emission test method that is still under development. Final action on these is not expected until 1993 and 1994 respectively.

Large chamber testing is widely recognized in the US and in much of Europe as the definitive technique for measuring formaldehyde emissions from wood-based panels. However, fundamental differences in test methodology between the US and European chamber test methods provide significantly different test results. These differences create confusion regarding product performance which leads to misunderstanding in the marketplace and in flawed proposals from the regulatory community. Considerable work has been done in the US and is currently underway in Europe to mere clearly describe and reconcile these differences. It is crucial that all parties come to a clear and mutual understanding of the differences in the two large scale test methods and the results therefrom. Unless these test methods and the results are fully and 
clearly reconciled, trade in PB and MDF products between the US and the EC will be adversely impacted.

To what extent do you feel that US conformity assessment systems relating to your sector are adequate for acceptance of test data or other attestations of conformity by the EC member states?

Typical US conformity assessment programs require daily monitoring of process variables and quality control testing, retention of detailed records of such monitoring, monthly inspections by third party representatives, and quarterly testing of certified products. These requirements by the conformity assessment organizations match or exceed the monitoring and testing requirements of any country in the world.

For example in so far as formaldehyde is concerned, the US has been blessed by having a standard Large Chamber test method that is widely accepted throughout North America. This test method, first developed in the early 1980's by the NPA and Hardwood Plywood Manufacturers Association, was embodied in a consensus standard in 1990 as ASTM E1333-1990, and is used by all US conformity assessment organizations and recognized by state and federal regulatory agencies as well as the model building codes. Most laboratories . have participated in industry wide round robin testing programs and there is consistency in test results among laboratories.

NPA believes that US conformity assessment programs for PB/MDF and the test data that they develop are well qualified to be accepted on a reciprocal bas is by the EC. NPA believes the federal government can facilitate this important mutual recognition.

Would your sector benefit from developing mutual recognition agreements between US laboratories or product certifiers and their EC counterparts?

The fundamental goal of US policy should be equal access for US products to the EC market and to minimize duplicate testing when the essential requirements are identical or technically equivalent. Manufacturer's self 
declaration of conformity should be allowed as an alternative to independent testing and certification or quality systems registration, in all instances where the underlying objective of the specific directive would not be compromised. US subcontracting entities should have the ability to perform all aspects of conformity assessment, including inspection, independent testing, certification and registration of manufacturers' quality systems, pursuant to the subcontracting arrangement.

NPA believes that mutual recognition agreements between the US and EC would be beneficial to the wood panel industry. For example, since the control of formaldehyde emissions from wood products are of growing international concern, mutual recognition of quality conformance organizations will be helpful in the future for establishing and maintaining new markets in Europe and elsewhere. NPA currently has bilateral subcontracting agreements with notified bodies of two EC countries. These agreements are for specific US manufacturers and specific products. They are narrow in scope and take a considerable amount of time and effort to initiate.

There are, however, certain obstacles that must be surmounted before mutual recognition agreements can be resolved. One obvious barrier is the non-uniformity of test methods for the wood-based panel product sector. Section 1.3 of the EC working document $(2 / 27 / 91)$ on mutual agreements notes that products "will have to comply with safety levels at least equivalent to those laid down in the laws of the two parties". For example, since the US and $E C$ countries use different formaldehyde test methods (see discussion in Question 2), agreement must be reached on acceptable means of converting test values to achieve equivalency.

Another concern is the representation on the negotiating teams. Mutual recognition agreements obviously mean that each side recognizes the conformity assessment programs of the other. It is much easier for the EC Commission to enter negotiations with EC-wide authority and the support of its constituents than any single party can for the US. Any negotiations on the part of the US should include not only government representation from Dept. of Commerce and other interested regulatory agencies (such as HUD and EPA), but representation 
from interested private sector groups such as the building codes, sector specific trade associations such as NPA, and other US product certifiers.

How can the US Government better utilize private sector input when developing official positions with regard to possible negotiations with EC for your sector for regulated products?

In advancing US interests in the EC, teams should include a mixed private/public sector approach. US teams formed to advance US interests in EC conformance matters must have technical leadership from the private sector. Associations and professional societies should be the principal resource on product specific matters. Private sector standards writing bodies also must play an appropriate role in advancing US interest. The exact mix of private and government representation on US delegations should be determined by the circumstances in each product sector.

The US Government and the private sector should encourage the EC to adopt procedures permitting non-EC experts to be non-voting participants with comment privileges in EC standards development activities. Access should be provided both to representatives of US technical committees directly supporting work in international standards bodies and to other non-EC experts. This need is pertinent to the development of test methods which will be used to evaluate products for conformance to specific regulations such as formaldehyde emissions requirements. Only through the direct and active participation of US experts at the EC working group level can the issues surrounding test method differences be first understood and ultimately resolved.

Under the present system where standards are written by EC technical committees and products are ultimately tested for conformance by a notified body, US manufacturers are second class participants in the EC market place. These manufacturers may already have a product certification program in place, but now they must find a notified body who will agree to certify their products to EC requirements. Under current scenarios, conformance testing will probably be done through a US subcontractor to an EC notified body. A 
better approach for certification testing would be EC recognition of US testing organizations as the equivalent of "notified" bodies. Ultimately, the best scenario would be mutual recognition agreements that allow products meeting certain requirements in either the US or EC countries to pass freely upon certification of conformance. Greater US participation in the standards development process will improve everyone's understanding of the differences between test methods which is a fundamental element of any mutual acceptance agreements.

Should "CE" marks of conformity be made acceptable in the US marketplace? What are the liability implications of such acceptance?

The question of whether "CE" marks of conformity be made acceptable in the US market place is difficult to answer. It is our understanding that the CE mark signifies that the product meets the essential requirements of the appropriate EC product directive. In some cases, the requirements of the EC product directive may not be equal to or exceed the product standard in the US. Making the CE mark "acceptable" here assumes that the EC essential requirements for that product are equal to or more demanding than those in the US Standards.

One possible alternative to accepting the CE mark in the US is to use the mark of the originating country's certifying or "notified" body as a "superscript" on the destination country's certifying or "notified" body's certification mark. For example, if Germany was the country of origin and the Wilhelm Klauditz Institut (WKI) was the in-country certifier, its mark would be a superscript on the US notified body (NPA for this example) mark: NPAWK1. Conversely, in the presence of a mutual recognition agreement, the NPA mark would be the superscript of the WKI logo for the German market: WKI NPA.

Using superscripts would notify the aser that the product has been tested in conformance with the destination country's essential product requirements by a qualified body. 
The issue of liability is one that should be an integral component of any mutual recognition negotiations. It is assumed that "product" liability always remains with the manufacturer. Any legal responsibility of the certifier, itself or through its subcontractor, is merely to conduct the appropriate monitoring, testing, and certification in accordance with whatever agreement governs this activity. In a subcontracting relationship, the parent organization, the "notified" body and/or the actual certifier, would presumably have final responsibility. The certifier's liability exposure should never extend to actual "product" liability.

\section{Does your sector need a recognizable mark of conformity? Is a US mark needed?}

In the EC, $\mathrm{PB}$ and MDF products sold as construction products will be required to meet certain essential requirements, specifically formaldehyde emissions limits. Under the guidelines of the Construction Products Directive there are specific product assurance requirements including use of the CE logo which signifies product conformance to the essential requirements of the Directive.

PB products sold in the US for construction applications are also regulated and require a specific mark or label indicating conformance to the pertinent requirements. There are several US organizations that provide independent product certification and conformance testing. These same organizations will ultimately provide testing services as sub-contractors and eventually as the equivalent of "notified" bodies for products going into the EC market.

Under mutual recognition agreements, products tested as conforming to specific requirements in either the US or the EC should be recognized in the other sector for specific applications. The use of superscript certification marks in conjunction with the CE mark in Europe and the appropriate standard reference in the US should satisfy the need for identification.

Respectfully submitted,

William Mccredie

Executive Vice-President 


\section{CERTIFICATION IN THE UK}

\section{TIMBER INDUSTRY}

by

Chris Shields

Director of Operations

TRADA Quality Assurance Services Limited 


\section{INTRODUCTION}

Certification of companies, products and people has been carried out in UK industry, including the timber industry, for many years. However, in common with all life, it has changed over that time, as has TRADA's role in this activity.

In this presentation I intend to show how TRADA's role has changed and to mention its current activities related to certification together with a summary of certification and accreditation in the UK.

Finally, I will mention the requirements for the European market, and particularly the use of the CE mark, as viewed from the UK.

TRADA

The Timber Research and Development Association, or TRADA as it is widely known, have carried out tests and issued test certificates for timber and timber products for many years. In 1977 it started its involvement in quality assurance by starting a scheme for the visual stress grading of timber. This was followed shortly after by its first product certification scheme, which was for trussed rafters.

Other schemes followed, but after discussions with Government we were advised that to obtain the formal approval of the Government we should set up a separate company to operate quality assurance schemes. The result of this advice was the formation of TRADA Quality Assurance Services Iimited (QAS) in 1987, and who now operate all of the quality assurance schemes formerly run by TRADA as well as a number of new schemes.

The final change at TRADA was the formation of TRADA Technology Limited (TTL) at the start of this year and they, among other things, carry out tests and issue test certificates.

This means that TRADA now has the two subsidiary companies of TRADA QAS and TRADA Technology.

\section{UR ACCREDITATION AND CERTIFICATION}

While TRADA was making its changes the background of accreditation and certification in the UK was also changing with strong pressure being exerted by the UR Government and major specifiers.

In 1981 there was the formation of a UR authority for the accreditation of testing laboratories and this is now known as National Measurement Accreditation Service (NAMAS).

In 1985 the National Accreditation Council for Certification Bodies (NACCB) was formed, and at the last count there were 18 Accredited Certification Bodies.

Accreditation has become based on a certification or testing body satisfying the relevant EN 45000 standard and a company who is approved having a quality system that complies with ISO 9000. 
The UK government's views on competition led to the creation of a number of Certification Bodies in various market sectors, and they have grouped themselves into the Association of certification Bodies. There are between 30 and 40 such bodies in the UK. Some of these operate in many sectors of industry whilst others only serve a particular sector, e.g. electrical industry.

In the past the main form of certification was product certification using a mark like the TRADAMARR, APA, or any grading agency mark. However in recent years the main interest has been the certification of quality systems against the ISO 9000 series of standards, and this has taken a significant hold in the UR for the supply of products; and activity has started in the supply of: services, e.g. training.

\section{TRADA QAS ACTIVITIES}

The position of TRADA QAS in the UR is that its Approved Quality Systems Scheme is accredited by the NACCB with over 80 registrations in the timber industry; these are based on system compliance with Iso 9000.

It operates product conformity schemes for timber products like trussed rafters and fire doors, and has just introduced a scheme for machine stress grading of timber, which is interesting some North American mills.

In addition it still has its original scheme for visual stress Grading to the British Standard BS 4978 with members in Norway and Denmark. It also runs training courses in grading both in the UK and overseas. In particular, in recent years its courses have been run in both canada and the USA - and more recently in the USSR.

The mark of membership of a TRADA QAS scheme depends upon whether it relates to a product or company system. For product schemes the TRADAMARK is used on the product itself whilst for system approval a different mark is used, but only on the company's documents.

\section{EUROPEAN MARKET}

Moving on now to Europe as a whole and in particular the Construction Products Directive. The first point to understand is that in some areas the UK's view is not the same as other countries, and that we are not yet ready to start using a European Mark.

The European Mark, 1.e. CE Mark, has not been made mandatory for Construction Products in the UK although all products must comply with the relevant European Standard, whenever they are ready. Also, the UK considers that the CE Mark indicates compliance with a minimum standard of safety and is not a quality mark. Therefore it expects existing quality marks to continue in use. The CE-Mark is likely to be made mandatory in most other Member States of the Community.

The European Standards will give technical requirements, levels of attegtation and guidance on factory production control. I will elaborate on both of the last two points shortly. I mentioned earlier that we are not yet ready to start using the mark and this is because the standards are not yet ready, and will not be ready for some time yet. 
The level of attestation will indicate what sort of certification or declaration of conformity is needed for a product. In simple terms there are 4 levels of attestation which vary from the company's own declaration to a requirement for testing, initial assessment and monitoring of a product and its production control system by an independent organisation. These organisations will be known as "notified bodies" and we expect TRADA QAS to be one of them.

However, no bodies are yet notified since this can only happen after a standard is ready.

Factory Production Control was mentioned earlier and this means the methods that are needed: to control the quality of a product. The requirements do not go as far as a full Iso 9002 system but are similar. UK companies have been advised to implement the full Iso 9000 system rather than stopping at the level of factory production only.

\section{AGREEMENTS}

In this context agreements means the different levels of discussions, and their conclusions, to assist international trade. A consultative document has been written in Europe on "Mutual Recognition with Third Countries" concerning the mutual recognition of conformity assessment. This does not mean sub-contracting, which I will deal with next.

The first level of negotiations and agreements are between Governments and must include consideration of GATT.

Agreements can also be made between Accreditation Authorities like the NACCB in the UK and the recently created Registrar Accreditation Board (the "RAB") in the U.S.

Lastly there may be agreements between certification bodies which may, or may not, be part of a larger Agreement Group recognised by the European Organisation for Testing and certification (the "EOTC"). This organisation will be responsible for voluntary agreements but at the moment it is uncertain whether it has any role in the regulatory sector, i.e. for products where EC marking is required.

\section{SUB-CONTRACTING}

One way in which operations could be arranged is for European Certification bodies to use agents in North America. This allows customers in Europe to have its products assured by an organisation, and using a quality mark, it knows well whilst reducing costs to the suppliers. TRADA QAS is already discussing this approach with some mills and grading agencies in North America.

A separate European consultative document has been produced on the use of sub-contractors or agents both within Europe and by third countries. The main rules of such arrangements would require the overall responsibility to stay with the original body. 
This would mean its involvement in the initial assessment and regular visits to the agent. It would also require that the staff used by the agent are suitably trained in assessment techniques, and I understand that such courses are available in the U.S.

\section{SUMMARY}

The purpose of this paper has been to explain some of the changes taking place in Europe on conformity assessment and marking. However, remember that all of the requirements are not in place and hence the CE mark can not yet be used.

The assessment methods that will be used require only minor changes to the existing UK system, and TRADA QAS activities. In fact one of the European standards has been adapted from our existing scheme.

The changes will mean an improvement and tightening of some standards of products used in Europe. However, there is no intention in the UK to let this adversely affect our timber imports from North America, since we will remain reliant on these imports for our industry.

cert.qgas 


\section{TOPICS}

COMPANY BACKGROUND

UK ACCREDITATION AND CERTIFICATION

EXISTING TRADA QAS ACTIVITIES

EUROPE

AGREEMENTS

USE OF SUB-CONTRACTORS

SUMMARY OF UK POSITION 


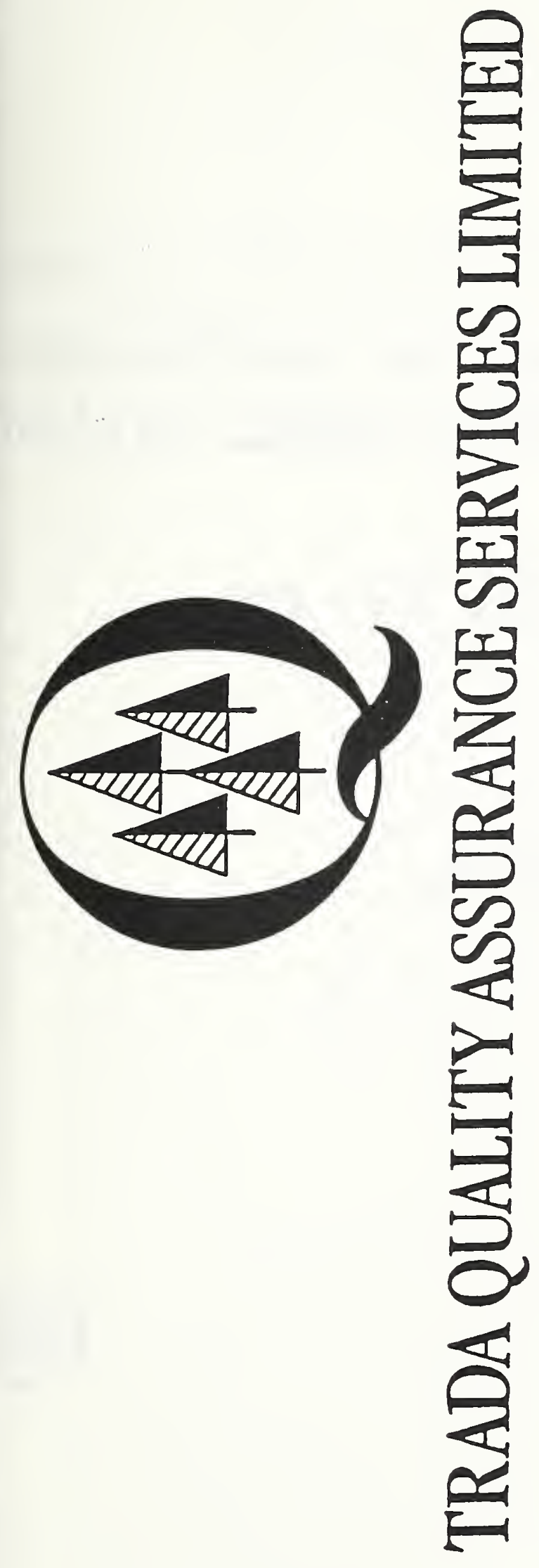

중 
EN45012 - General criteria for certification bodies operating quality system certification

ISO 9000 - Quality Systems 
SSOCIATION OF CERTIFICATION BODIES

\section{$30-40$ COMPANIES IN UK}




\title{
TRADA QAS LTD ACTIVITIES
}

\author{
VISUAL STRESS GRADING
}

PRODUCT SCHEMES

MACHINE STRESS GRADING

APPROVED QUALITY SYSTEMS 

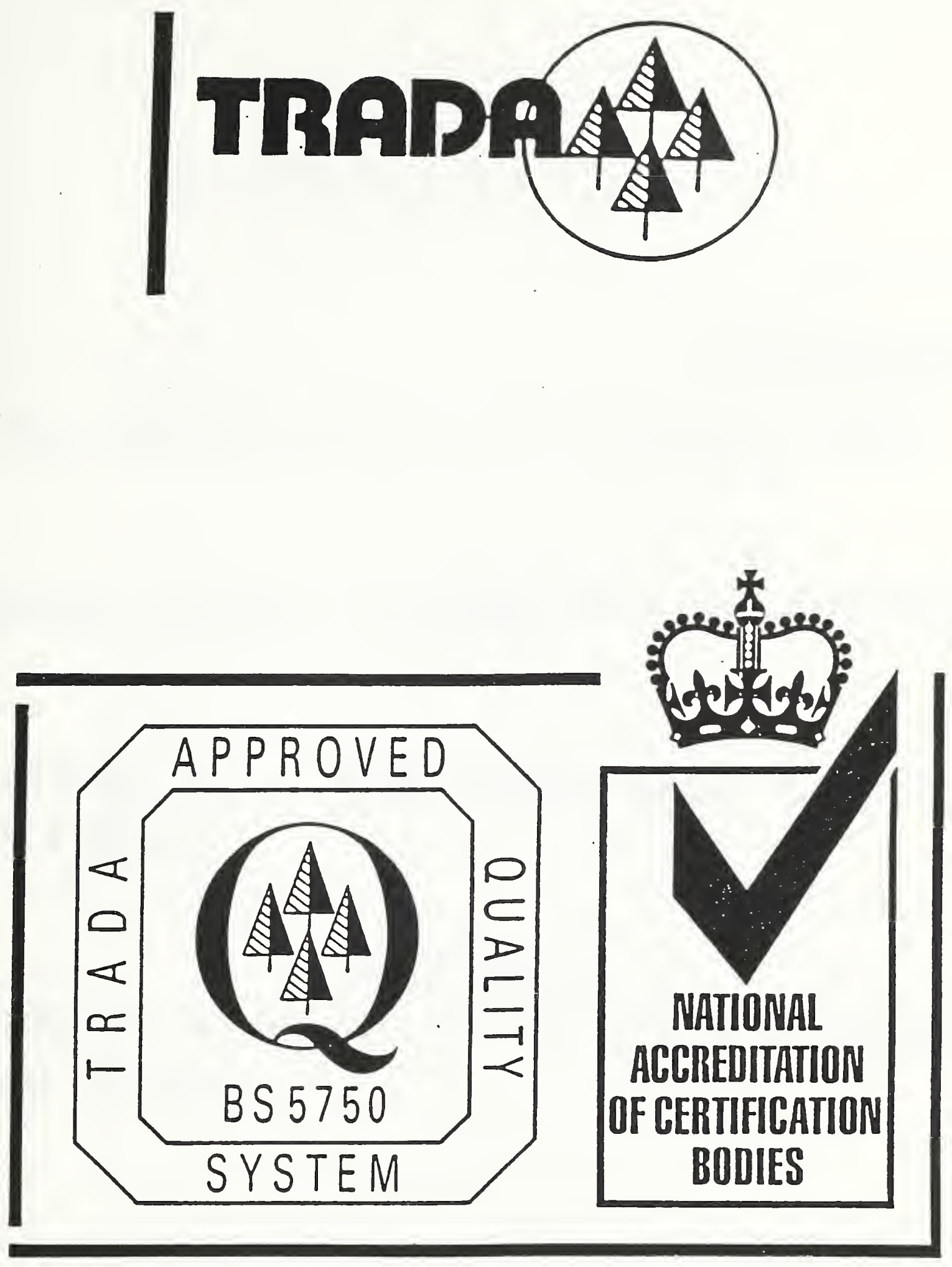


\section{EUROPE -}

CE MARK

ATTESTATION

STANDARDS 


\section{ATTESTATION LEVELS}

FULL PRODUCT CONFORMITY BY NOTIFIED BODY

\section{INITIAL TESTING AND CONTROL BY NOTIFIED BODY}

\section{NOTIFIED BODY TESTING AND COMPANY DECLARATION OF CONTROL}

COMPANY DELARATION OF TESTING, CONFORMANCE AND. CONTROL 
ISO 9000

"QUALITY SYSTEMS"

9001

DESIGN/DEVELOPMENT

PRODUCTION,

INSTALLATION

AND SERVICING

9002

PRODUCTION AND INSTALLATION

9003

FINAL INSPECTION AND TEST

PLUS GUIDANCE DOCUMENTS 


\title{
AGREEMENTS
}

\author{
GOVERNMENT
}

\section{ACCREDITATION BODIES}

CERTIFICATION BODIES 


\section{RULES FOR NOTIFIED BODY}

RETAIN RESPONSIBILITY

INITIALLY ASSESS COMPANY

AUDIT AGENT

ENSURE SUITABLY TRAINED STAFF 

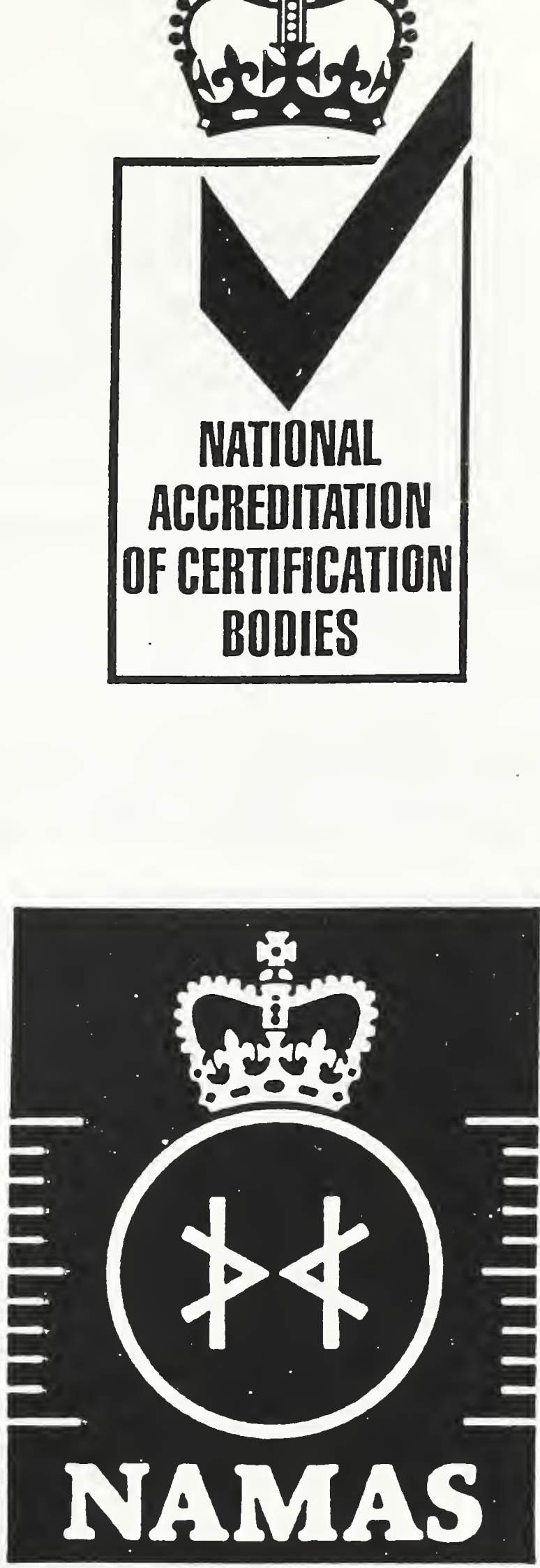
Gentlemen,

Quality simply is not the most expensive product you can get but the one that is fit for purpose. Mr. Charles Ludolph told what the final situation in the EC will be, when do we have to deal with the situation. Now, my speech should be seen in this respect. The aim of certification is to try to specify very carefully minimum requirements for a product and a way to test this. These requirements for a product are not set up by the certification body itself but is done by an independent committee consisting of representatives from:

$$
\begin{aligned}
& \text { - producers, } \\
& \text { - customers, and } \\
& \text { - independent experts. }
\end{aligned}
$$

The result of this work is handed over to the Board of experts. This board of experts is put together from representatives of Research organisations, government, building authorities etc.

No representative of certificate holders are allowed to be members of course. When this board of experts concludes that the work is done according the regulations; the assessment guide is accepted and published by the certification body. Certificates can be given out to interested parties in this field.

Where are we talking about when we say in the Netherlands: certified construction products? There are many kinds of construction products available which are manufactured in companies at home and abroad, which are certified by Dutch certification bodies or certified under the responsibility of these certification bodies by their sister organizations abroad.

All certified products are construction products for the residential-, utility-, road-, and waterway construction sectors. Either architects and engineers are the ones who have the responsibility for the approval or disapproval of construction products, or the municipalities which have tasks on the building site in this respect, or the Ministry of Housing as subsidizing body.

The approval activities for building products move from building site to factory and from individuals to professional organizations. The professional organizations are in the Netherlands eight certification bodies, all members of VECIBIN.

There are four bodies which have been established by trade and industry itself; examples of which include:

- the certification body stichting BMC, productcertification (for raw materials, for mortars and concrete, ready mixed concrete and mortars);

- stichting Keuringsbureau Hout SKH, productcertification, quality systemcertification and attestation (for timber, timber products and timber constructions);

- stichting Kwaliteitscentrum Gevelelementen, productcertification (for metal and plastic windows; and for hardware fittings); and the fourth;

- stichting IKOB, productcertification (for aerated concrete blocks; ceramic tiles; bricks and mortars).

The other 4 certification bodies work in the field of electricity, water supply etc.

Each of the certification bodies have their own certification mark, but seven of the eight certification bodies use the KOMO mark for construction products. 908 of the manufacturers which are certified in the Netherlands deliver their products with the Komo mark. 
In some special occasions a certification body could allow to use other marks as well. SKH for instance, allowed a group of manufacturers all producing more or less the same product to use an existing mark as the certification mark. I point herewith to the APA mark. In Europe this mark is well known as a certification mark.

The organization of certification in the construction industry in the Netherlands.

Now that we know what certified construction products are, it might be of mutual interest to know how the certification bodies in the Netherlands are working. How could otherwise certification bodies from different countries in Europe work together without knowing this? The experience in the Netherlands is anyway, that if you really want to co-operate and to recognize each others certificates, than you have to start to tell what you are doing and why.

The working method from all certification bodies in the Netherlands is in general that the certification body draws up the principles of assessment, and thereafter conducts an investigation in the manufacture and of the products, where-upon a positive assessment means that a quality declaration may be granted.

\section{Principles}

A manufacturer who want a quality declaration for certain construction products, applies to the certification institute as stated before; for Timber, Timber products and Timber construction to SKH. He then receives the evaluation guidelines in which all technical conditions are to be found which must be met by product and production process.

\section{Product}

The point of departure in the evaluation guidelines is that the product will fit for purpose. The certification body determines that with the aid of performance requirements related to use, together with product requirements specific to that product. In an evaluation guideline is also to be found a code of practice, if necessary.

If there is a standard available for that particular product, then this part of the evaluation guideline refers to that standard and the text in the guideline is kept brief.

\section{Production Process}

With regard to the evaluation of the production process the evaluation guideline contains always requirements for the quality system and where appropriate, those for the laboratory equipment. It may be clear that the evaluation guideline is a very important tool of the certification body and has to be ready, before the pre-certification inspection can take place.

During the pre-certification inspection the design, the product, the production process and/or the processing process are assessed dependently from the type of quality declaration being applied for.

What we call quality declarations are certificates, agreements, European technical approvals, etc. If the result of the pre-certification inspection is favorable, the producer shall qualify to use the relevant quality declaration. 
A quality declaration has the following parts:

- statement of the certification body that the product is suitable for a certain use/purpose/application;

- that the products are controlled regularly; so they where with an approved prototype;

- that the production process is in accordance with the requirements mentioned in the evaluation guideline; and at last

- that the products are marked.

A specification of the product is given, recommendations are made with regard to the application, and recommendations are given how the approval by architects upon their delivery can be granted. Quality declarations ranges from 20 down to 2 pages.

How can these certification bodies with their various working methods, arrive at a equivalent assessment of construction products and/or processes? Equivalency should be the base for implementation of the quality declarations in the new legislation in the Netherlands and in the Construction Products Directive in Europe.

In the Netherlands the following situation is reached.

In order to arrive a regularly and orderly certification system, the Minister of Economic Affairs in the Netherlands established the Foundation Council for Certification in Juli 1981.

The council distinguishes between four certification systems:

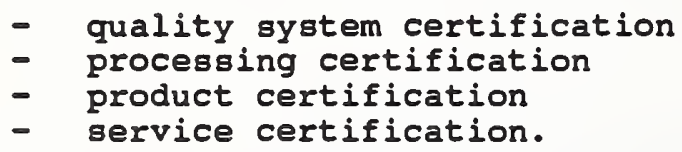

The council has assessed $\mathrm{SKH}$ and her certification systems on the base of accreditation criteria, and thereafter recognized their certificationsystems for Timber construction products.

How do we see these typical Dutch quality declarations in the broader scope of Europe?

The basis for certification is, as said before, an Assessment Guide.

In these assessment guides relevant standards, productions requirements, control equipment, etc., are mentioned.

With an eye on the EC market and the expected open borders between the member states European Standards produced by the CEN committees are also taken up. However there is a difficulty. Existing CEN and also ISO standards for 908 only give test methods, countries who accepted these standards were supposed to formulate their own requirements and that leads to a problem in the European acceptance of the quality declaration as well. In order to obtain an equality, certification bodies made bilateral contracts with certification bodies in other countries. A good example of this kind of harmonisation can be found in our organisation. SKH have now contracts with certification and control organisation in 5 countries in Europe, in Malesia, Indonesia and in the United States. Last week a contract with the Forintec in Vancouver was settled.

In the new European Product standards however this situation will be totally different. Not only test methods and requirements but also a classification and rules for certification of products should be incorporated in these standards. 
The new system gives much more room to producers of the products to define their products.

Classification of the requirements gives the member states the possibility to classify or to define their products more clearly.

As an example I will give you a classification for window frames in which our standardisation Committee "Doors and windows" defined a window frame for the use in a $40 \mathrm{~m}$ high building along the coastline.

Here we see that the European approach differs from countries abroad. On the other hand when a windowframe manufacturer from the U.S. should want to export his products to one of the EC countries he won't in this respect be stopped by a protection policy of the EC as long as he proves that his products meets the requirements mentioned in the standard and proves that he carefully followed the decision tree mentioned in the guidance paper nI 8 Choice of conformity Attestation Procedure published by the EC in order to get the so called CE-mark. There are obstacles however, I'll come to the later. This decision tree is quite difficult to understand but if you follow it to the letter you will come to one of the classes.

Well to come back to the CEN committees.

The CEN Technical Board not only decides upon the working program of the TC's but also decides whether a Technical Committee gets a mandate on this working program or not. This is very important matter because having your working program mandated means:

1. The TC gets money for the necessary research to underbuild standards and that

2. The standards produced will be taken up in the EC Building directives.

This now is very important because only certified products can be used in new buildings and building under renovation.

In this respect Product Certification and in some cases Quality system Certification will be necessary in order to get into this market. Let us presume that you want to come into the European market let us say in 1992.

There are two possibilities:

1. You just produce products more or less according to the specification of the independent states. With the exception of the price you will find not many barriers but that will mean that your products for Holland will and must differ from those for Germany or Italy.

2. You apply for a recognised certificate, I mean product certificate, and you ask at the same time for an Attestation of Conformity. The certification Institute will than put its effort to get this Attestation of Conformity in Brussels for you. Once you have that-your market will be much more interesting. There is a problem here because Attastation of conformity is not yet implemented for all products- that could take a lot of time.

Now the situation in 1993 (Europe is still believing that 1993 will come in this century ()

Following the decisiontree you will find out in what category your product or product groups can be classified. If that is 1 or 2 you contact an independent certification body and once certified you apply there for a CE-mark.

However this certification institute must be a so called nominated body in Brussels (for the wood sector SKH).

As a nominated body there is a opportunity to get a so called Technical Approval. TA are given out by the EOTA = European Organisation for Technical Approvals. The basis for this approval are the so called essential requirements. 
Products or groups of products of which the manufacturer can prove that they meet this requirements could obtain these TA.

The ER relate to:

1. Mechanical resistance and stability

2. Safety in case of fire

3. Hygiene, health and environment

4. Safety in use

5. Protection against noise

6. Energy economy and heat retention.

We already started up the procedure to get a TA for the APA.

SKH also applied for harmonisation in the fields of wood adhesives, load and nonload bearing laminated timber structures and other fields will follow.

Now I get to the problem for countries outside the EC. In principle there are no borders economically seen except for the fact that you must prove that you product is fit for purpose. Well there are borders when you read the small letters. One of the most important things is that in all official documents the following is written: the manufacturer responsible for the product or his agent established in the community.... This could give a problem of course only larger firms could allow themselves an agent in Europe.

Now you see that it is very important to follow what is going on in the European standard Committees. I do know that it is extremely expensive to attend CEN meeting. I myself am a member of 4 Technical Committees and within this TC's I participate in 6 working groups and 8 Task-groups.

If you only imagine that you have to meet each other at least 4 times a year than you understand that this is really expensive.

I do not expect you to do the same thing but if you only could be 0 (Observing) members of the technical committees you would receive the documents and learn what is going on and maybe you could react by writing. Do not think you could not influence the work, there are o-members working in Task-groups already and they not only influence our work but contribute expertise.

There is some American involvement in CEN already; not direct but through their European representatives. Again a good example is the APA who is member of the CEN committee "Sheat material".

Europe after 1993 will be a very big market with some 300 million potential customers and if I may say so a reach market with a need for high quality products. We know that the USA produced the top gurus in Quality Assurance and that quality in the factories is on a high level of standard.

I also know that building products produced in the USA are produced in Europe as well and that European standard do not differ much from those used in the USA. We experienced that the certified American products generally speaking meet the requirements in Europe its is only a matter of knowing that we are doing things our way and that you understand how to deal with it. The years passed that we Dutch concluded contracts with American firms and that we learned that as soon as the home market in the USA got willing again we had to learn that those contracts were worthless.

We experience nowadays very serious partners, with products of a high standard. We need lumber like the UK. 
HOW TO BE ALLOWED TO USE THE EC CONFORMITY MARK AND THUS TO SELL PRODUCTS WITHIN THE EUROPEAN MARKET?

HOW TO BE IN ACCORDANCE WITH THE EUROPEAN. HARMONIZED STANDARDS?

HOW TO GET A

EUROPEAN. TECHNICAL APPROVAL?

Your Partners in Germany for Germany and the European Communities

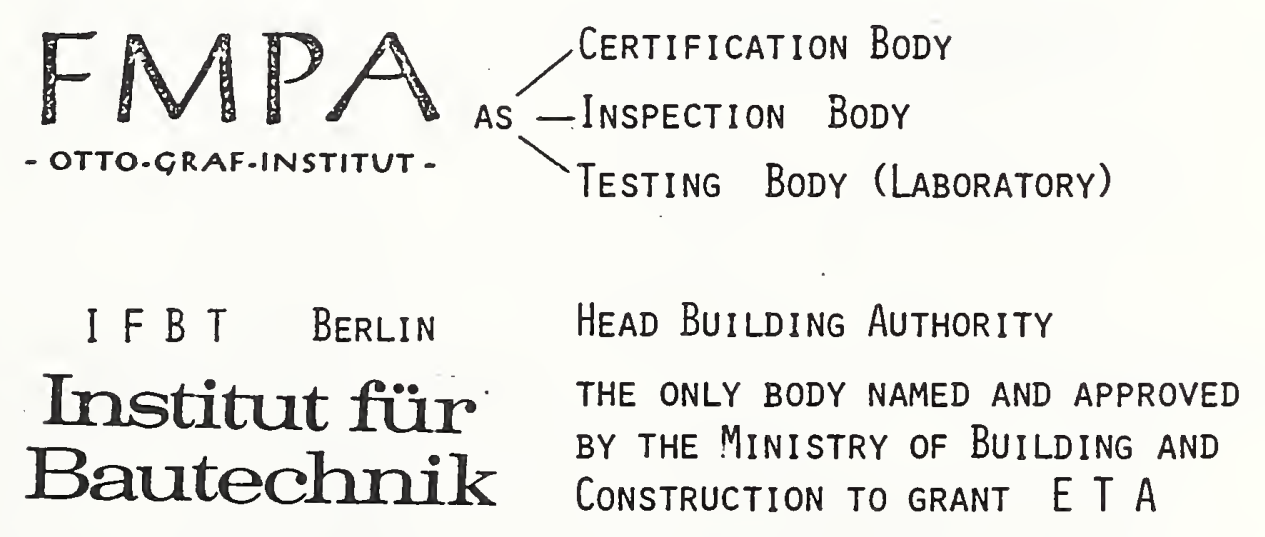


BADEN-WURTTEMBERG - OTTO-GRAF-INSTITUT -

\section{INSTITUTION}

FMPA Baden-württemberg

-otto-Graf-Institut-

Research and Materials Testing

Institute

Pfaffenwaldring 4

D-7000 Stuttgart 80

Tel.: $++49711 \quad 685 \quad 2280$
(2284) Fax:
Head of Institute: Hans-Wolf REINHARDT

Head of Dept.14 (Wood): Gerhard WERNER

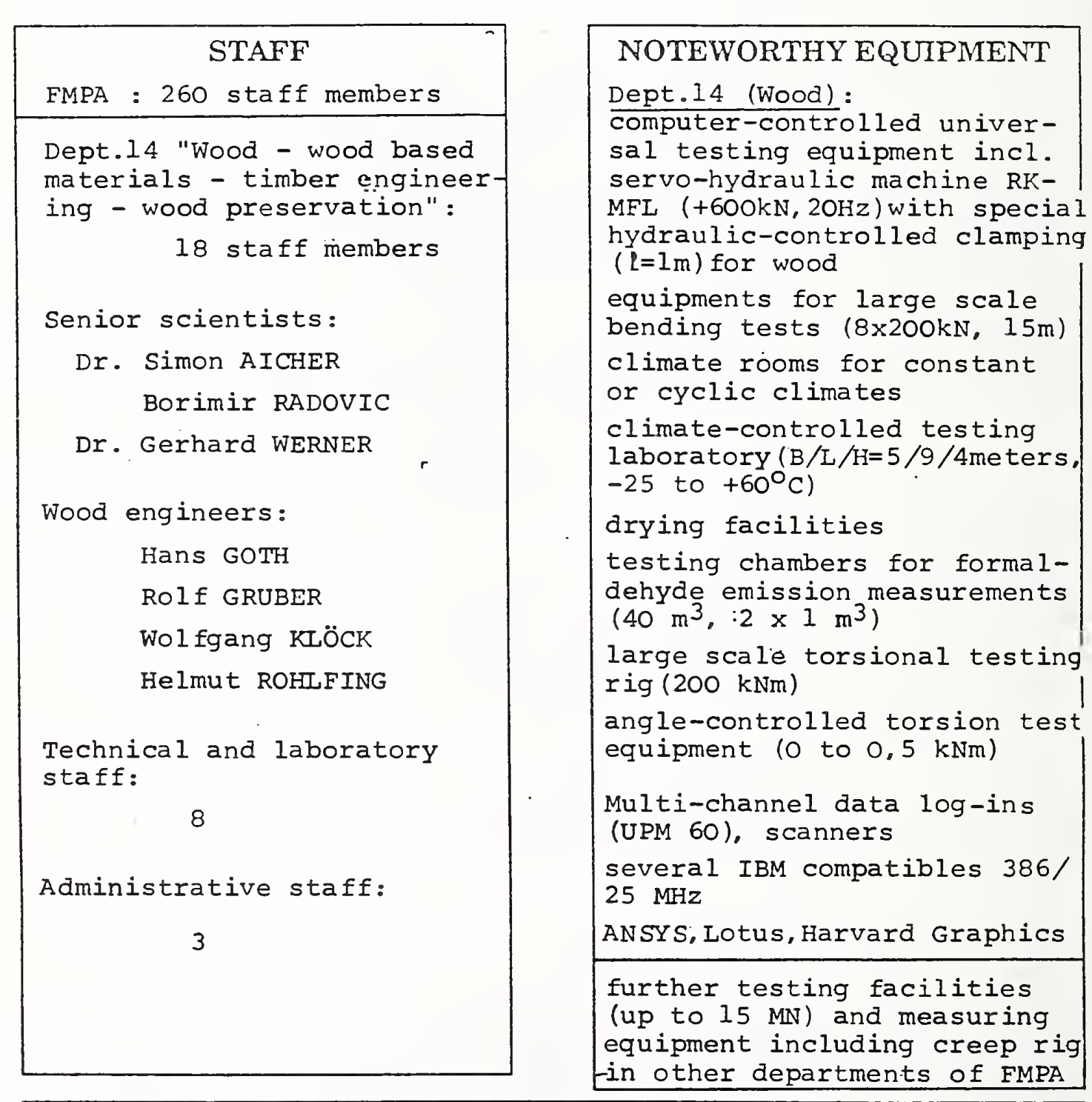

$++497116856829(6820)$

\section{KEY WORDS}

wood, wood based materials, panels, glulam, timber structures, composite structures, prefabricated elements, adhesives, connectors - reliability, quality control, quality assessment, certification, restoration, preservation, expertise (damages). wood mechanics, creep, duration of load, influence of climate (temperature, moisture), continuum and fracture mechanics 

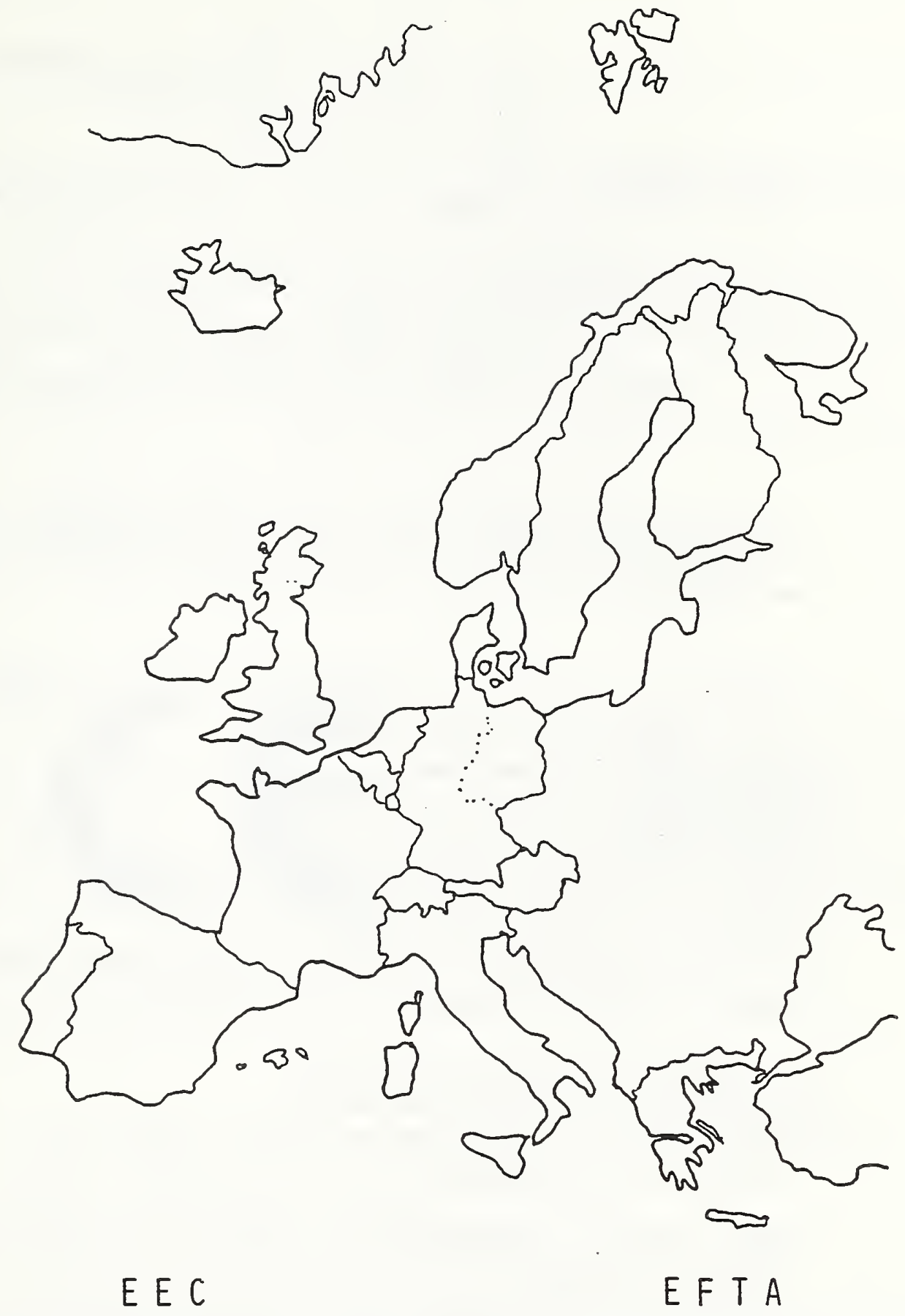

\section{European Economic Community}

European Free Trade Association

$\begin{array}{lrll}\text { Germany } & 10 & \text { Belgium } & 5 \\ \text { France } & 10 & \text { Netherlands } & 5 \\ \text { Italy } & 10 & \text { Greece } & 5 \\ \text { Great Britain } & 10 & \text { Danmark } & 3 \\ \text { Spain } & 8 & \text { Ireland } & 3 \\ \text { Portugal } & 5 & \text { Luxemburg } & 2\end{array}$

Austria Sweden

Switzerland Norway

Liechtenstein Finland

Iceland

380 Millions C ON S U M E R 
I S 09000 Quality Management and Quality Assurance Standards GUIDELINES FOR SELECTION AND USE

(Identical with EN 29 000)

\begin{abstract}
I S 09001 Quality Systems - Model for Quality Assurance in Design/Development, Production, Installation and Servicing (Identical with EN 29001 )

I S 09002 Quality Systems - Model for Quality Assurance in Production and Installation (Identical with EN 29 002)

I S 09003 Quality Systems - Model for Quality Assurance in Final Inspection and Test (Identical with EN 29 003)

I S 09004 Quality Management and Quality System Elements - Guidelines (Identical with EN 29004 )
\end{abstract}

Whereas the objective pu'sued in EN 29002 is widely spread, the Construction Products Directive (CPD) is only concerned - in the framework of its procedure of attestation of conformity - with ensuring that the product conforms with the relevant $E$ u r o p e a $\mathrm{n}$ e chn ic a 1 S pecif ications.

\title{
C O UNCIL D I RECTI IVE 89/106/EEC FROM. DECEMBER 1988 C P D Construction Products Directive
}

Commission of the European Communities "Internal Market and Industrial Affairs" THE STANDING COMMITTEE FOR CONSTRUCTION

Appendix I: Essential Requirements Stability - Fire - Health, environment Safe Use - Acoustics - Energy Saving

Appendix II: European Technical Approval (E T A )

Appendix III: Attestation of Conformity according to Technical Specifications

Appendix IV: Approval of Testing, Inspection, Surveillance and Certification Bodies

based on CPD : 5 Guidance Papers III/D-2.

Guidance Paper No. 5 (III/4330/90-EN) Construct 90/064 February 1991

- Information to Accompany the EC Mark for Construction Products

Guidance Paper No. 7 (III/4331/91-EN) Construct 91/067 February 1991

- Guidelines for the Performance of the Factory Production Control for Construction Products

Guidance Paper No. 8 (III/4032/91-EN) Construct 91/068 February 1991

- Choice of Conformity Attestation Procedure

Guidance Paper No. 9 (III/4039/91-EN) Construct 91/072 March 1991

- Guidelines for the Certification of Construction Products by an Approved Certification Body

Guidance Paper No.10 (III/4040/91-EN) Construct 91/073 March 1991

- Guidelines for the Assessment and Certification of the Factory Production Control by an Approved Body 
Guidance Paper No. 5

INFORMATION TO ACCOMPANY THE EC MARK FOR CONSTRUCTION PRODUCTS

Construction Products: Materials, elements, components and prefabicated systems which contribute to meet the Essential Requirements

Guidance Paper No.5 intends to facilitate the implementation of the respective provisions of the C P D in European Standards and guidelines for European Technical Approval (and the European Technical Approval themselves). It is addressed to the specification writers ( CEN, E O T A ) for consideration together with the respective mandates and provisions given therein.

CPD Construction Products Directive 89/106/EEC december 1988

CEN European Committee for Standardization

EOTA European Organisation for Technical Approvals

EC CONFORMITY MARK
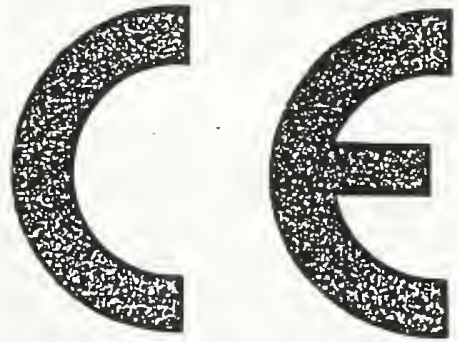

Accompanying Information:

- Name of the producer and plant

- Products identity

- Specification (EN... ETA...)

- Year of manufacture

- Number of EC certificate or EC declaration of conformity
E C
C E R T I F I C A T E
$O F$
CONFORMITY
- Name and address of the certification body

EC DECLARATION OF CONFORMITY presented in the official language or languages of the Member State in which the product is to be used

C E N members should strongly be encouraged to reflect $E N$ codes in their national system

Reference numbering system for $E T A$ 's has to mention Member State number, approval body and the E T A - number 
TECHNICAL SPECIFICATIONS

$\begin{array}{lll}\text { European Harmonized Standards EN ... } & \text { edited by C E N } \\ \text { European TeChnical Approvals ETA ... } & \text { granted by E } 0 \text { T a } \\ \text { (National Techical Specifications) } & \text { if EN or Eta are not yet available }\end{array}$

EUROPEAN HARMONIZED STANDARDS CEN

Technical Committees (TC) dealing with wood and wood based products

tC 38 - Durability of Wood and Wood Based Products

EN $330-335-350-351$

TC 103 - Adhesives for Wood and Derived Timber Products EN $204-301-302$

TC 112 - WoOd BAsed PANels (number of items) $s \mathrm{t}$ a $\mathrm{n} d$ a $r \mathrm{~d} s$
W G 1 - Particle bords (16)
WG 2 - Plywood (20)
WG 3 - Fibreboards (15)
W G 4 - Common test methods for wood based panels (17)
WG 5 - Formaldehyde (3)
WG 6 - Cement bonded particle boards (9)
EN 309-311-312-317-319
EN $313-314-315$
EN $316-317-318-319-320-321-382$
EN $310-322-323-324-325-326$
EN 120

TC 124 - Timber Structures

$\begin{array}{llll}W G & \text { - Test Methods } & (16) \\ W G & 2 & \text { - Solid Timber } & (8) \\ W G & 3 & \text { - Glulam } & (6) \\ W G & 4 & \text { - Connectors } & (2)\end{array}$

EN $380-383-408$

EN $336-338-384-518-519$

EN $385-386-387-390-391-392$

TC 127 - Fire Safety in Buildings

TC 175 - Round, Sann and Processed Timber

Scope: Standardisation in all uses excluding structural aspects

TC 250 - Structural EuRocodes ( 8 SUbCommissions)

SC 5: EUROCODE 5 Design OF Timber Structures 
WG 1 (Test nsethods)

\begin{tabular}{|c|c|c|c|c|}
\hline EN TC 124.101 & $87 / 10.021$ - prEN 380 & Timber sruaures - General principles for static loading & $1990-06-30$ & $1991-02-08$ \\
\hline EN TC 124.102 & $87 / 10.025$ & $\begin{array}{l}\text { Wood based panels in strucural sizes - Determination of some physical and } \\
\text { mechanical properties for structural purposes }\end{array}$ & $1991-06-30$ & . \\
\hline EN TC 124.103 & $87 / 10.023 \cdot \mathrm{prEN} 408$ & $\begin{array}{l}\text { Solid timber and glued laminated timber - Determination of some physical and } \\
\text { mechanieal properties for structural purposes }\end{array}$ & $1990-06-30$ & $1991-04-03$ \\
\hline EN TC 124.104 & $87 / 10.024-p r E N 383$ & Timber struaures - Determination of embedding strength & $1990-06-30$ & 1991-02-16 \\
\hline EN TC 124.105 & $87 / 10.022$ & $\begin{array}{l}\text { Solid timber in struaural sizes and glued luminated timber - Determination of } \\
\text { lensile, compresswe strengiths and stifnesses perpendicalar to the grain }\end{array}$ & $1991-09-30$ & \\
\hline EN TC 124.106 & $87 / 10.026$ & Timber struaures - Timber framed walls - Racking strength and stiffness of walls & $1991-06-30$ & \\
\hline EN TC 124.107 & deleted & & & \\
\hline EN TC 124.108 & $87 / 10.041$ & Timber structures - Testing of trusses & $1991-06-30$ & \\
\hline EN TC 124.109 & $87 / 10.044$ & Timber structures - Testing of strucural floor decking & $1991-12-31$ & \\
\hline EN TC 124.110 & $87 / 10.045-$ prEN 409 & Timber strucures - Determination of the yield moment of dowel npe fasteners & $1990-09-30$ & 1991-04-03 \\
\hline EN TC 124.111 & $87 / 10.043$ & Timber strucures - The tessing of timber framed structural wall sheathing & $1991-06-30$ & \\
\hline EN TC 124.112 & & Timber structures - Testing of load bearing nailed joints & $1991-12-31$ & \\
\hline EN TC 124.113 & & Timber strucrures - Tessing of load bcaring stapled joints & $1991-12-31$ & \\
\hline EN TC 124.114 & & Timber structures - Testing of nail withdrawal & $1991-12 \cdot 31$ & \\
\hline EN TC 124.115 & & Timber srucuures - Testing of nail head pull through & $1991-12-31$ & \\
\hline EN TC 124.116 & (ISO 8969/28969) & Timber structures - Testing of punehed metal plate fasteners & $1991-12.31$ & \\
\hline
\end{tabular}

CEN TC 124 Secretariat - Numbering list of drafts for standards

WG 2 (Solid timber)

\begin{tabular}{|c|c|c|c|c|}
\hline EN TC 124.201 & $87 / 10.029 \cdot \operatorname{prEN} 336$ & Siruciural timber - Permissible deviations and preferted sizes & $1990-06 \cdot 30$ & 1991.02 .08 \\
\hline EN TC 124.202 & $87 / 10.032$ - prEN 384 & $\begin{array}{l}\text { Strucuural timber - Determination of eharacteristic values of mechanical properties } \\
\text { and density }\end{array}$ & $1990-06-30$ & $1991-02-16$ \\
\hline EN TC 124.203 & $87 / 10.027$ - prEN 338 & Sinuaural timber - Sirengih elasses & $1990-06-30$ & $1991-02-08$ \\
\hline EN TC 124.204 & 87/10.031 pr.EN518 & Strucuural timber - Grading - Requirements for visual strength grading standards & 1991.03 .31 & \\
\hline EN TC 124.205 & $87 / 10.033$ pr EN 519 & $\begin{array}{l}\text { Structural timber - Grading - Requirements for machinc gress graded timber and } \\
\text { grading machines }\end{array}$ & $1991-03.31$ & \\
\hline EN TC 124.206 & $87 / 10.042$ & Wood based materials - Determination of charaacrissie values & $1991-09-30$ & \\
\hline EN TC 124.207 & $87 / 10.030$ & Glued laminated timber - Strength classes & $1991 \cdot 06-30$ & \\
\hline EN TC 124.208 & $87 / 10.040$ & $\begin{array}{l}\text { Strucural timber - Production requiremeais for fabricated trussed rafters using } \\
\text { punched metal fasteners }\end{array}$ & $1991-09-30$ & \\
\hline
\end{tabular}

CEN TC 124 Secretariat - Numbering list of drans for standards

WG 3 (Glulani)

\begin{tabular}{|c|c|c|c|c|}
\hline \multicolumn{3}{|l|}{ ( ) } & \\
\hline EN TC 124301 & $87 / 10.028-$ prEN 390 & Glued laminated timber - Dimensions - Permissible deviations & $1990-06-30$ & $1991-02-16$ \\
\hline EN TC 124302 & $87 / 10.034-\operatorname{prEN} 385$ & Finger jointed structural timber & $1990-06-30$ & $1991-02-16$ \\
\hline EN TC 124303 & $87 / 10.035 \cdot$ prEN 386 & Glued laminated timber - Production requirements & $1990-06 \cdot 30$ & $1991-02-16$ \\
\hline EN TC 124304 & $87 / 10.036$ - prEN 391 & Glued laminated timber - Delamination tests of glue lines & $1990-06-30$ & $1991-02 \cdot 16$ \\
\hline EN TC 124305 & $87 / 10.037$ - prEN 392 & Glued laminated timber - Glueline shear test & $1990-06-30$ & 1991.02 .16 \\
\hline EN TC 124306 & $87 / 10.039$ - prEN 387 & Glued laminated timber - Producion requirements for large finger joints & $1990-06-30$ & $1991-02-16$ \\
\hline
\end{tabular}

\section{CEN TC 124 Secretariat - Numbering list of drafs for standards}

WG 4 (Connectors)

TC 124 t.d. CEN i.d.

\begin{tabular}{|l|l|}
\hline EN TC 124.401 & $87 / 10.099$ \\
\hline EN TC 124.402 & $87 / 10.100$ \\
\hline
\end{tabular}

Timber fasteners - Specifications for connectoxers for timber

Timber fasteners - Characeristic inad-eaming capacities and slip-moduli

1991-12-31

$1991-12-31$ 
Essential Requirements (E.R.'s) are:

Stability - Fire - Health, Environment - Safe Use - Acoustics - Energy Saving

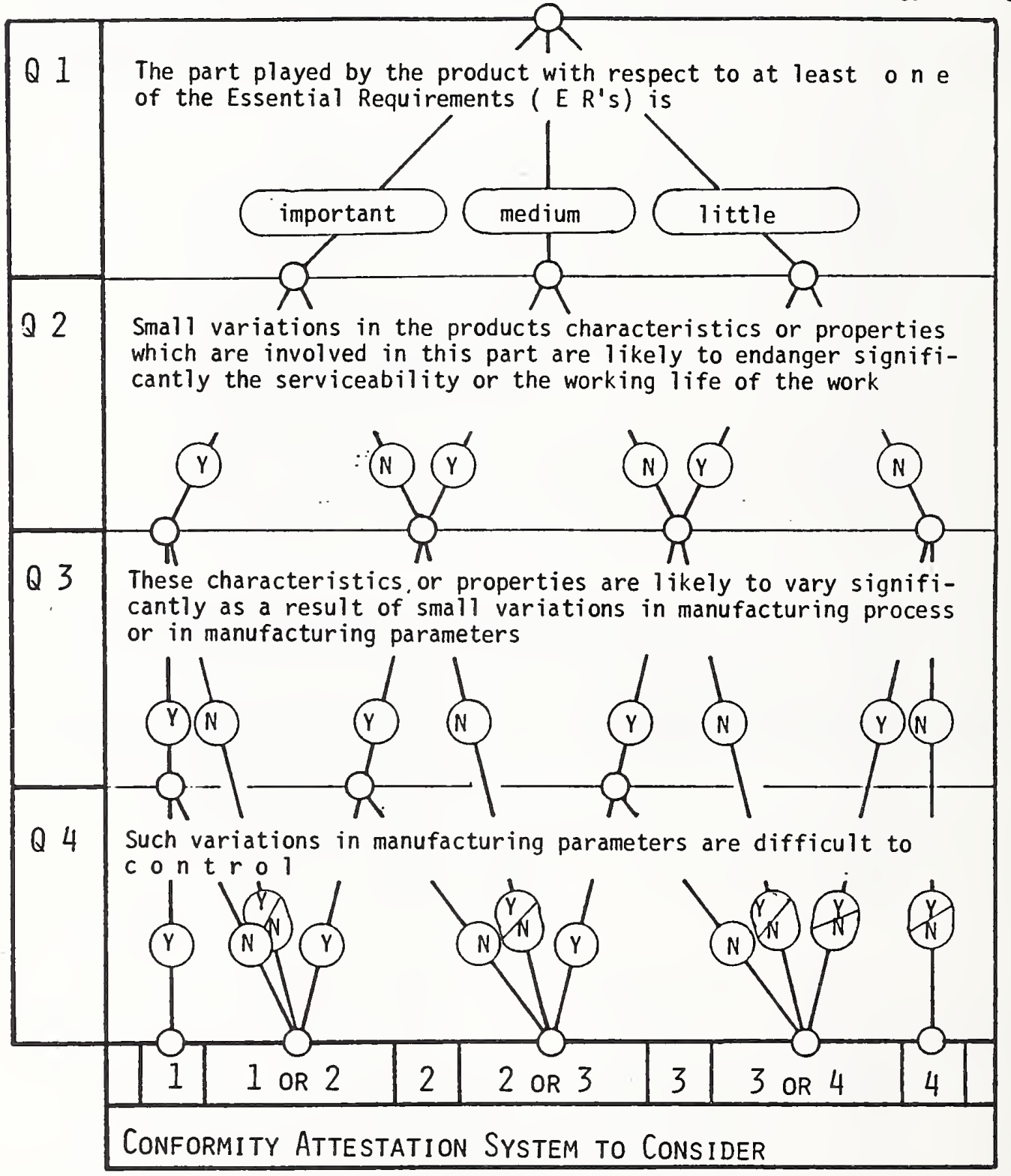

\section{Conformity Attestation Systems}

1 certification of the conformity of the product by an approved certification body

2 declaration of conformity of the product by the manufacturer, with certification of factory production control by an approved body

3 declaration of conformity of the product by the manufacturer, with initial type testing by an approved body and factory production control by the manufacturer

4 declaration of conformity of the product by the manufacturer, with initial type testing and factory production control by the manufacturer 


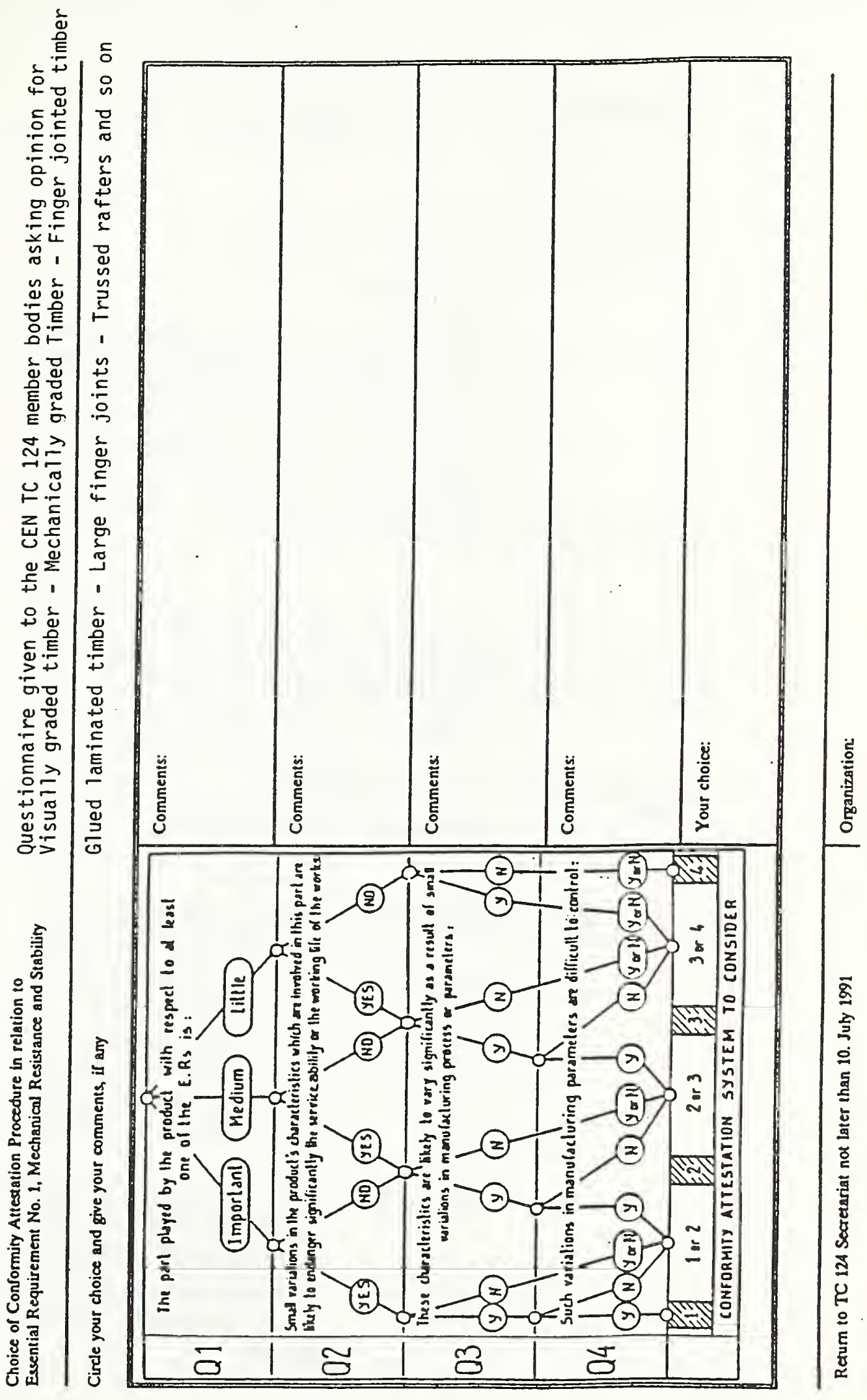

81 


$$
\begin{aligned}
& \text { EN } 45001-45002-45003 \\
& \quad 45011-45012-45013-45014 \\
& \text { GENERAL CRITERIA (TESTING LABORATORIE: }
\end{aligned}
$$

\section{Foreword}

This European Standard has been drawn up with the objective of promoting confidence in those laboratories which conform to it. In order to arrive at this result, the various relevant European and international documents have been examined.

This standard forms part of the following series of standards covering testing, certification and accreditation:

EN 45001 General criteria for the - operation of testing laboratories

EN 45002 General criteria for the assessment of testing laboratories

EN 45003 General criteria for laboratory accreditation bodies

EN 45011 General criteria for certification bodies operating product certification

EN 45012 General criteria for certification bodies operating Quality System certification

EN 45013 General criteria for certification bodies operating certification of personnel

EN 45014 General criteria for suppliers' declaration of conformity 
This European Standard has been drawn up with the objective of providing the general criteria for producing the supplier's declaration of conformity in order that $c$ o $n f$ ide $n c e$ in it can be achieved

Annex $A$ (informalive)
7 Recommended form of declaration of conformity

\section{DECLARATION OF CONFORMITY}

We

(supplier's name)

(adclevose)

declare under our sole responsibility that the product

(name, lype or model, lol, baicli or serial number, possibly sources antu munbers of iforns)

to which this declaration relates is in conformity with the following slandard(s) or other normative document(s)

(lille and/or flumber and dalo of issue of the slandard(s) or oller normalive document(s))

(il applicablo)

following the provisions of Directive

(Place and dale of issue)

(namo and signalure or equivalen) marking of authorized person) 
NIST-114A

(REV. 3-0)
U.S. DEPARTMENT OF COMMERCE

NATIONAL INSTITUTE OF STANDARDS AND TECHNOLOGY

BIBLIOGRAPHIC DATA SHEET
1. PULUCATION ON REPOAT MULEES

NISTIR 4771

2 PERFOAMINO ORCANIZATION REPORT HULEER

2 PULUCATIOH DATE

MARCH 1992

4. TIRE AND SUCTITE

Conformity Assessment Workshop on Wood Products

5. AUTHON(3)

Robert L. Gladhill

6. PERFORMIHO OROMIRATION (NF JOHT ON OTHEA THW MIST, SEE INSTRUCTIOHS)

U.S. DEPARTMEAT OF COMLERCE

MATIOHAL INSTITUTE OF STAMDANDS AHD TECHNOLOOY

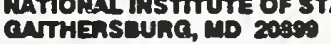

7. CONTMCT/ORAT MULEE

2. TYPE OF REPOAT AND PERIOD COVERED NISTIR

9. SPOMSOAHO ORONIZATION MUE AND COMPLETE ADDNESS (STRET, CTY, STATE, ZIT)

American Plywood Assoc., Tacoma, WA 98411

National Forest Products Assoc., 1250 Conn. Ave., NW, washington, DC 20036

American Lumber Standards Committee, 19715 Waters Rd., Germantown, MD 20875

10. SUPPLEMENTAY MOTES

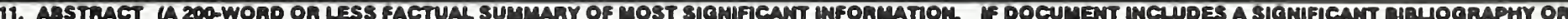
UTERATURE SUAVEY, METTOH $\pi$ HERE)

On November 6, 1991, the National Institute of standards and Technology NIST) cosponsored a workshop with the American Plywood Association (APA), the National Forest Products Association (NFPA), and the American Lumber standards Committee (AISC). The purpose was to explore ways in which the U.S. Government could assist the wood products industry in conformity assessment activities aimed at gaining acceptance of their products in such international markets as the European Community (EC). This report describes the discussions which were held and provides the recommendations produced.

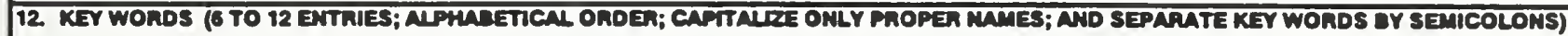
conformity assessment; EC 92, forest products; international trade; lumber; plywood; wood products

13

13. AVNLANIUTY

UREurmed

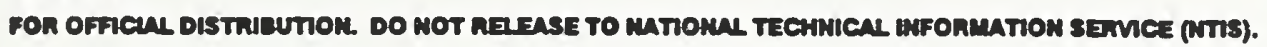

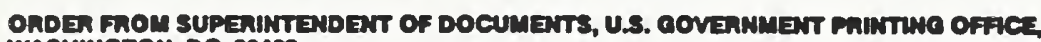
WAstuncton, De 20402

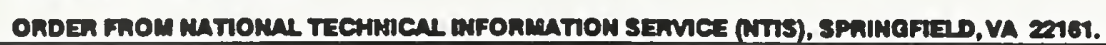

14. MUMBEA OF PAINTED PACES

83

15. PRICE

A05 

